\section{ERS/ESTS clinical guidelines on fitness for radical therapy in lung cancer patients (surgery and chemo-radiotherapy)}

\author{
A. Brunelli*, A. Charloux*, C.T. Bolliger, G. Rocco, J-P. Sculier, G. Varela, M. Licker, \\ M.K. Ferguson, C. Faivre-Finn, R.M. Huber, E.M. Clini, T. Win, D. De Ruysscher and \\ L. Goldman on behalf of the European Respiratory Society and European Society of \\ Thoracic Surgeons joint task force on fitness for radical therapy
}

ABSTRACT: A collaboration of multidisciplinary experts on the functional evaluation of lung cancer patients has been facilitated by the European Respiratory Society (ERS) and the European Society of Thoracic Surgery (ESTS), in order to draw up recommendations and provide clinicians with clear, up-to-date guidelines on fitness for surgery and chemo-radiotherapy.

The subject was divided into different topics, which were then assigned to at least two experts. The authors searched the literature according to their own strategies, with no central literature review being performed. The draft reports written by the experts on each topic were reviewed, discussed and voted on by the entire expert panel. The evidence supporting each recommendation was summarised, and graded as described by the Scottish Intercollegiate Guidelines Network Grading Review Group. Clinical practice guidelines were generated and finalised in a functional algorithm for risk stratification of the lung resection candidates, emphasising cardiological evaluation, forced expiratory volume in $1 \mathrm{~s}$, systematic carbon monoxide lung diffusion capacity and exercise testing.

Contrary to lung resection, for which the scientific evidences are more robust, we were unable to recommend any specific test, cut-off value, or algorithm before chemo-radiotherapy due to the lack of data. We recommend that lung cancer patients should be managed in specialised settings by multidisciplinary teams.

KEYWORDS: Chemotherapy, lung cancer, pre-operative evaluation, pulmonary resection, radical therapy, radiotherapy

\section{CONTENTS}

Introduction

Methods

Cardiological evaluation before lung resection

Lung function tests and exercise tests

Spirometry and diffusing capacity of the lung for carbon monoxide

Split function studies

Exercise tests

Future trends in pre-operative work-up

Patient care management

The role of rehabilitation before and after lung resection surgery

Scoring systems: do they have a place in patient selection?

Do we need to send all thoracotomies to the ICU?

Residual function and QoL after radical treatment
AFFILIATIONS

${ }^{*}$ ERS/ESTS task force co-chair. For author affiliation details, please refer to the Acknowledgements section.

CORRESPONDENCE

A. Brunelli

Division of Thoracic Surgery

Umberto I Regional Hospital Ancona

Italy

E-mail: alexit_2000@yahoo.com

Received:

Dec 042008

Accepted after revision:

Feb 242009 
Surgical techniques in lung cancer

Combined cancer surgery and lung volume reduction

surgery

Compromised parenchymal sparing resections and minimally invasive techniques: the balance between oncological radicality and functional reserve . . . . . . . . . . . . . . . 27

Chemo-radiotherapy in lung cancer . . . . . . . . . . . 28

Neoadjuvant chemotherapy and complications . . . . . . . 28

Definitive radiotherapy and chemotherapy: functional selection criteria and definition of risk. Should surgical criteria be re-calibrated for radiotherapy and chemotherapy?

\section{INTRODUCTION}

A joint task force of multidisciplinary experts on the functional evaluation of lung cancer patients was endorsed by the European Respiratory Society (ERS) and the European Society of Thoracic Surgery (ESTS) in order to draw up recommendations and provide clinicians with clear, up-to-date guidelines on fitness for surgery and chemo-radiotherapy.

During the past years, an abundance of literature related to pre-operative evaluation before surgical treatment of lung cancer has been published. Indeed, despite refinement of medical treatments, lung resection remains the only curative treatment of lung cancer. Therefore, offering a surgical chance to patients deemed to be at high surgical risk remains highly relevant. The recent advances in operative, and also peri-operative management, as well as in the reassessment of traditional lung function tests and exercise test modalities, justify reviewing the functional evaluation before surgery for lung cancer. However, since only $20-25 \%$ of lung cancer patients are operable, and because of the widespread use of neoadjuvant chemotherapy, most patients are treated with chemo and/or radiotherapy. These treatments have specific toxicities, including for the lung, which should be taken into account when elaborating treatment strategy. In this view, this task force also aimed to review the literature on the assessment of acute and long-term risks related to chemoradiotherapy, to determine if the surgical criteria could be "re-calibrated" for radiotherapy and chemotherapy. The remit of the task force was also to make recommendations, for patients who are not eligible for surgery, on alternative nonsurgical treatments. Ideally, guidelines should give the physician a basis to evaluate the benefit/risk ratio related to each therapeutic option offered to his patient. Whether the available literature allows this goal to be achieved will be discussed.

\section{METHODS}

The task force was composed of 14 invited participants, identified on the basis of their expertise in the area of lung cancer. The subject was divided in different topics, which were in turn assigned to at least two experts. The authors searched the literature according to their own strategies, with no central literature review being performed. The draft reports written by the experts on each topic were distributed to the entire expert panel, and comments solicited in advance of the meetings. During the meetings (held at the 2008 ESTS and at the 2008 ERS congresses), the recommendations were reviewed, discussed and voted on by the entire panel. Additional papers from

The patient at prohibitive surgical risk: alternatives to surgery . . . . . . . . . . . . . . . . . . . 30 Who should treat thoracic patients and where should they be treated?

Multidisciplinary management . . . . . . . . . . . 30

Quality of lung cancer surgery . . . . . . . . . . . . . 30

Quality of radiotherapy ... . . . . . . . . . . . . . 31

Algorithm for the assessment of risk before lung

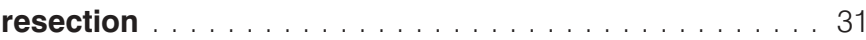

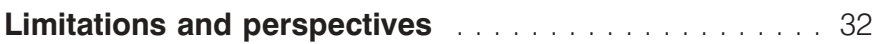

References ........................ 32

personal files were added if required. Approval required consensus, which was defined as an overwhelming majority approval. Differences of opinion were accommodated by revising the recommendations, the rationale or the grade, until consensus was reached. The evidence supporting each recommendation was summarised, and recommendations graded as described by the Scottish Intercollegiate Guidelines Network Grading Review Group: grades of recommendation are based on the strength of supporting evidence, taking into account its overall level and the considered judgment of the guideline developers (table 1) [1].

\section{CARDIOLOGICAL EVALUATION BEFORE LUNG RESECTION}

Substantial data (table 2) can aid the pre-operative evaluation of cardiac risk for lung resection surgery [2-6], and guide interventions to reduce that risk [2-30]. After a well-validated index provides estimates of patient's risk [2-5], more detailed evaluation should be based on the individual patient characteristics [5-8]. Detailed evaluation for coronary heart disease generally is not recommended in patients with an acceptable exercise tolerance, such as the ability to walk up two flights of stairs without stopping [6-8]. If exercise capacity is limited, noninvasive testing can identify a relatively small proportion of patients for new or intensified control of heart failure, arrhythmias, or myocardial ischaemia. Appropriately aggressive cardiac interventions should be instituted prior to surgery in patients who would need them irrespective of the surgery, but interventions specifically for surgery are of limited benefit. For example, prophylactic coronary revascularisation does not reduce risk [30]. Furthermore, recovery after coronary bypass surgery may take several months, and the need for aggressive anti-platelet therapy, which is recommended for $\sim 6$ weeks after coronary angioplasty and/or a bare metal stent and for $\geqslant 1 \mathrm{yr}$ after a drug-eluting stent, presents a major challenge in the peri-operative context [31,32].

Beta-blockers reduce peri-operative myocardial infarction significantly $[19,23]$, but commonly used beta-blocker regimens increase the risk of stroke, presumably due to bradycardia and hypotension, and can increase overall mortality, perhaps by interfering with stress responses in critically ill patients [22]. In patients with very advanced coronary disease, in whom the risks of myocardial infarction are especially high, the cardioprotective benefits of short-acting beta-blockers, whose potential deleterious effects are easier to reverse, may outweigh their bradycardic and hypotensive effects [23]. Alternative adrenergic modulation, such as with clonidine 
TABLE 1 Scottish Intercollegiate Guidelines Network (SIGN) grading system for recommendations in evidence based guidelines

Levels of evidence
$1++$
$1+$
1
$2++$
$2+$
2
3
4
Grades of recommendations

A

B

C

D
High-quality meta-analyses, systematic reviews of RCTs, or RCTs with a very low risk of bias Well-conducted meta-analyses, systematic reviews of RCTs, or RCTs with a low risk of bias Meta-analyses, systematic reviews or RCTs, or RCTs with a high risk of bias

1) High-quality systematic reviews of case-control or cohort studies, or 2) high-quality case-control or cohort studies with a very low risk of confounding, bias, or chance and a high probability that the relationship is causal

Well-conducted case-control or cohort studies with a low risk of confounding, bias, or chance and a moderate probability that the relationship is causal

Case-control or cohort studies with a high risk of confounding, bias, or chance and a significant risk that the relationship is not causal

Nonanalytical studies, e.g. case reports and case series

Expert opinion

1) At least one meta-analysis, systematic review, or RCT rated as $1++$ and directly applicable to the target population, or 2) a systematic review of RCTs or a body of evidence consisting principally of studies rated as $1+$ directly applicable to the target population and demonstrating overall consistency of results

1) A body of evidence including studies rated as $2++$ directly applicable to the target population and demonstrating overall consistency of results, or 2) extrapolated evidence from studies rated as $1++$ or $1+$

1) A body of evidence including studies rated as $2+$ directly applicable to the target population and demonstrating overall consistency of results, or 2) extrapolated evidence from studies rated as $2++$

1) Evidence level 3 or 4 , or 2) extrapolated evidence from studies rated as $2+$

RCT: randomised controlled trial. Reproduced from [1] with permission from the publisher.

and related drugs [24-26], may be useful, but larger randomised trials will be required to evaluate $\alpha_{2}$-adrenergic agonists, statins [29] and other potential peri-operative interventions.

Recommendations are given in table 2, and summarised in an algorithm (fig. 1). Patients at low cardiological risk or with an optimised cardiological treatment may proceed with the following pulmonary evaluation.

\section{LUNG FUNCTION TESTS AND EXERCISE TESTS Spirometry and diffusing capacity of the lung for carbon monoxide}

Limitations of predicted post-operative forced expiratory volume in $1 \mathrm{~s}$

In the two most commonly used functional algorithms for the pre-operative evaluation of lung resection candidates [33, 34], the predicted post-operative (ppo)-forced expiratory volume in $1 \mathrm{~s}$ (FEV1) is pivotal in choosing further tests or even excluding patients from operation without further tests.

Many case series have shown that peri-operative risks increase substantially when ppo-FEV1 is $<40 \%$ of predicted, reporting mortality rates ranging 16-50\% [35-39]. NAKAHARA and coworkers $[40,41]$ found a mortality rate as high as $60 \%$ when ppo-FEV1 was $<30 \%$.

In a larger series, KEARNEY et al. [42] found that ppo-FEV1 was the best predictor of complications after controlling for the effect of other risk factors in a multivariate analysis.

However, others have reported better results in very small numbers of patients with lung function this poor [43-46].

More recently, BRUNELLI et al. [47] showed that ppo-FEV1 was not a reliable predictor of complications in patients with preoperative FEV1 $>70 \%$. Furthermore, in those patients with a
ppo-FEV $1<40 \%$, the mortality rate was only $4.8 \%$. These findings have been partly explained by the so-called "lung volume reduction effect" that can reduce the functional loss in patients with airflow limitations. In this regard, many studies have already shown the minimal loss, or even improvement, in pulmonary function after lobectomy in lung cancer patients with moderate to severe chronic obstructive pulmonary disease (COPD), questioning the traditional operability criteria mostly based on pulmonary parameters [48-55]. Recently, BRUNELLi et al. [56] and VARELA et al. [57] have shown that this lung volume reduction effect takes place in the immediate post-operative period.

A value for ppo-FEV1 of $40 \%$ is currently used to distinguish between normal risk and higher risk lung resection patients [58]. However, given the recent strong improvement in perioperative management and surgical techniques, and based on data collected by the present experts, we suggest that this limit should be lowered to $30 \%$ (fig. 2).

\section{Immediate post-operative estimation of pulmonary function}

Although ppo-FEV1 is fairly accurate in predicting the definitive residual value of FEV1 3-6 months after surgery $[37,40,53,60-66]$ it substantially overestimates the actual FEV1 observed in the initial post-operative days, when most complications occur [67].

VARELA et al. [67] showed also that on post-operative day 1 after lobectomy the actual FEV1 was 30\% lower than predicted and as a result was a better predictor of complications than was ppo-FEV1 [68]. According to this finding, an attempt should be made to predict early FEV1 after lobectomy [69] and pneumonectomy. 


\section{TABLE 2 Assessing and addressing cardiac fitness for radical lung cancer surgery}

\section{Estimating pre-operative cardiac risk}

Summary recommendation

Noninvasive stress tests

Identifying patients with aortic stenosis

Echocardiography

\section{Cardiological approaches for reducing risks}

Patients with hypertension

Patients with pulmonary hypertension or congenital heart disease

Patients with hypertrophic cardiomyopathy

Patients with heart failure or arrhythmias

Pulmonary artery catheterisation

Peri-operative beta blockade

Peri-operative $\alpha$-adrenergic modulation

Other anti-ischaemic medications

Peri-operative use of HMG-CoA reductase inhibitors (statins)

Peri-operative coronary revascularisation
Patients should be risk stratified using validated risk indexes, which should direct any additional testing (recommendation grade $B$, evidence level $2++$ ).

Patients with 1) poor functional status (<4 METs) and 1-2 RCRI criteria, and 2) a history of angina or claudication should be generally appropriate for noninvasive testing to assess risks for surgery (recommendation grade $\mathrm{B}$, evidence level $2++$ ). Patients at $>20 \%$ risk according to initial estimates (RCRI $>3$ ) may still have high peri-operative risks, despite a negative noninvasive study ( $>5 \%$ post-test probability with negative test) (recommendation grade B, evidence level 2++).

However, treatment strategies based on the results of non-invasive testing are not of proven value.

Patients with physical findings consistent with aortic outflow tract obstruction should have pre-operative echocardiography (recommendation grade $\mathrm{B}$, evidence level $2++$ ).

Pre-operative echocardiography should also be obtained when other valvular disease, left ventrical dysfunction, or pulmonary hypertension is suspected, according to published guidelines (recommendation grade B, evidence level 2++)

Anti-hypertensive medications should be given up to the morning of surgery and be continued orally or intravenously as soon as possible post-operatively (recommendation grade D, evidence level 4).

Beneficial chronic therapies could be generally recommended during the peri-operative period (recommendation grade D, evidence level 4)

Management could be similar to the chronic setting (recommendation grade D, evidence level 4).

Elective surgery could be delayed if heart failure or arrhythmias are unstable, meet accepted criteria for new interventions, or are likely to represent inadequately treated ischaemic heart disease. Optimal management of patients with stable heart failure or adequately treated arrhythmias could adhere to published guidelines (recommendation grade D, evidence level 4).

Few, if any, noncardiac surgery patients must receive routine pulmonary artery catheterisation (recommendation grade A, evidence level $1++$ ).

Patients with ischaemic heart disease generally do not benefit from newly prescribed peri-operative beta blockade (recommendation grade $\mathrm{A}$, evidence level 1++), but beta blockers should be continued in patients who are already taking them (recommendation grade $B$, evidence level $2++$ ) and may be beneficial as new therapy in very high-risk patients (recommendation grade $\mathrm{B}$, evidence level 1).

Modulation of the $\alpha$-adrenergic systems with drugs such as clonidine may be beneficial for vascular surgery but are of even [24-26] less certain benefit for other operations (recommendation grade A, evidence level 1+).

Prophylactic nitrates can reduce ischaemia but not major events; prophylactic calcium channel blockers could be of uncertain benefit (recommendation grade B, evidence level 2++).

Statin lipid-lowering agents could be started before noncardiac surgery whenever long-term lipid-lowering therapy is indicated (recommendation grade D, evidence level 4).

Patients at high risk clinically or based on noninvasive testing must be considered for diagnostic catheterisation. Coronary revascularisation must be recommended only for patients who would benefit in the absence of the planned surgery (recommendation grade $A$, evidence level $1++$ ).
Spirometry should be performed according to the joint ERS/ American Thoracic Society (ATS) clinical practice guidelines [70].

\section{Recommendation}

The ppo-FEV1 should not to be used alone to select patients with lung cancer for lung resection, particularly patients with moderate to severe COPD. It tends to underestimate the functional loss in the early post-operative phase and does not appear to be a reliable predictor of complications in COPD patients. A ppo-FEV1 value of $30 \%$ pred is suggested to be a high risk threshold for this parameter when included in an algorithm for assessment of pulmonary reserve before surgery (fig. 2). Level of evidence 2+; grade of recommendations $\mathrm{C}$.

\section{Statement}

An attempt to predict immediate post-operative pulmonary function seems to be recommendable at least on an investigational basis. Level of evidence 2 . 


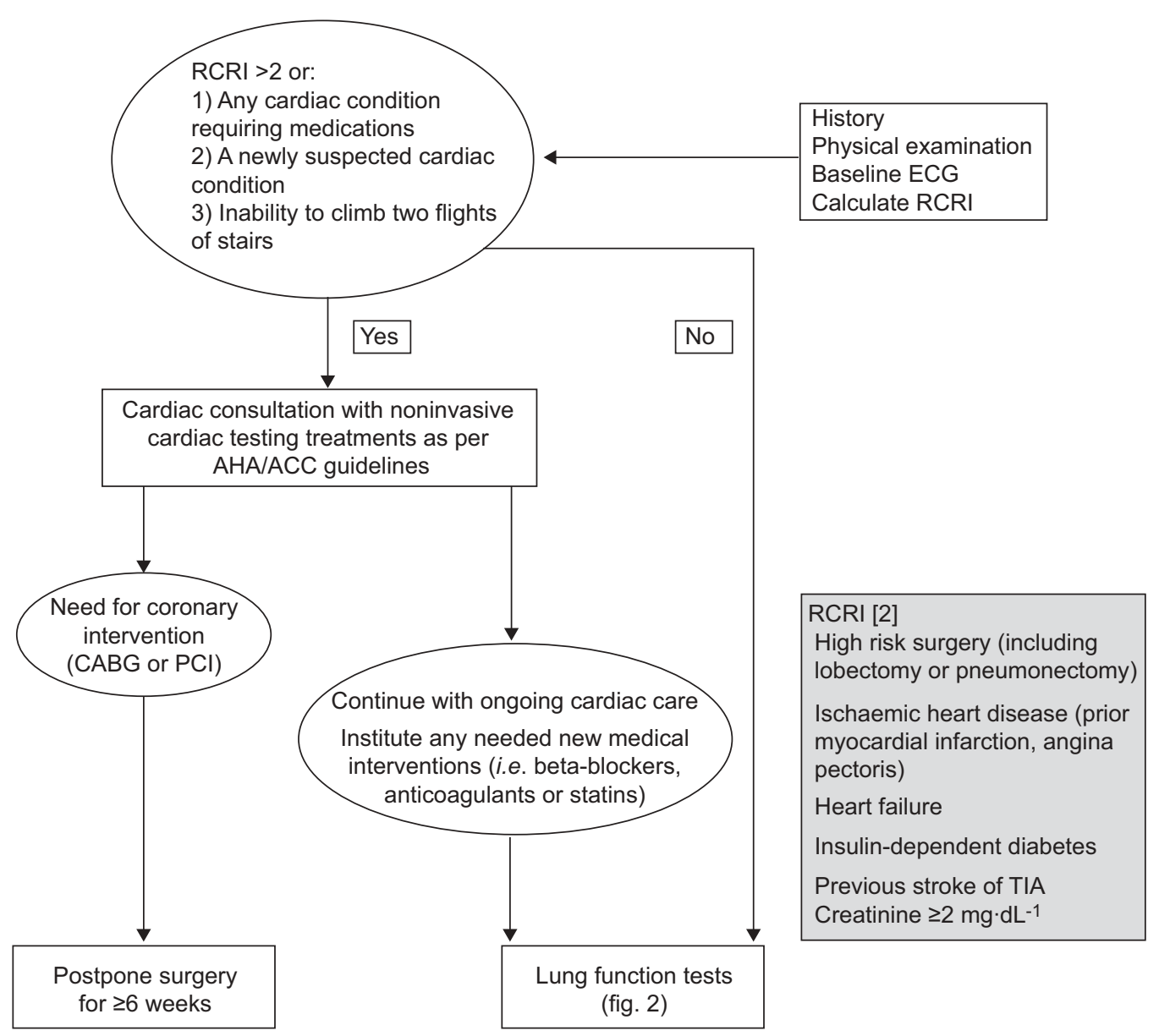

FIGURE 1. Algorithm for cardiac assessment before lung resection in lung cancer patients. For American College of Cardiology Foundation/American Heart Association (AHA/ACC) guidelines see [2-6]. CABG: coronary artery bypass graft; PCI: primary coronary intervention; TIA: transient ischaemic attack.

Diffusing capacity: systematic or selective use in the assessment of candidates for radical therapy for lung cancer

The diffusing capacity of the lung for carbon monoxide $(D \mathrm{~L}, \mathrm{CO})$ is a valuable proxy measurement for alveolar oxygen exchange in the assessment of the lung resection candidate. Early reports demonstrated that DL,CO decreased after lung resection [71$74]$, and that a low DL,CO was associated with an increase in operative mortality after major lung resection [75]. In the late 1980s, DL,CO was first shown to be an independent predictor of post-operative mortality and morbidity after lung resection. Subsequently, similar findings have also been reported by others [37, 38, 76-80]. A low pre-operative DL,CO was related to an increased frequency of readmission to the hospital and a poorer long-term quality of life (QoL) [81]. The utility of the per cent ppo-DL,CO as the single strongest predictor of outcomes in unselected patients was subsequently identified [82]. A value for ppo-DL,CO of $40 \%$ currently is used to distinguish between normal risk and higher risk lung resection patients [58]. However, given the recent strong improvement in peri-operative management and surgical techniques, and based on data collected by the present experts, we suggest that this limit should be lowered to $30 \%$ (fig. 2).

One controversial issue is whether diffusing capacity should be measured only in patients who have compromised spirometric function. In the Society of Thoracic Surgeons' general thoracic database, only $57 \%$ of patients undergoing major lung resection had DL,CO values reported (unpublished data). In the European Thoracic Surgery database, $<25 \%$ of such patients had DL,CO measured [83]. Published guidelines suggest that $D L, C O$ be measured only in patients with compromised per cent FEV1 [34, 84]. However, recent studies demonstrate that diffusing capacity is very important in predicting post-operative complications, even in patients with a normal FEV1 ( $>80 \%$ pred) or without COPD (FEV1/forced vital capacity ratio $>0.7)[58,85]$. These studies demonstrate that diffusing capacity is a strong predictor of post-operative complications in patients regardless of COPD status.

DL,CO measurement should be performed according to the joint ERS/ATS clinical practice guidelines [86].

\section{Recommendation}

$\overline{D L, C O}$ should be routinely measured during pre-operative evaluation of lung resection candidates, regardless of whether the spirometric evaluation is abnormal. A ppo-DL,CO value of $30 \%$ pred is suggested to be a high risk threshold for this parameter when included in an algorithm for assessment of pulmonary reserve before surgery (fig. 2). Level of evidence $2++$; grade of recommendation $\mathrm{B}$. 


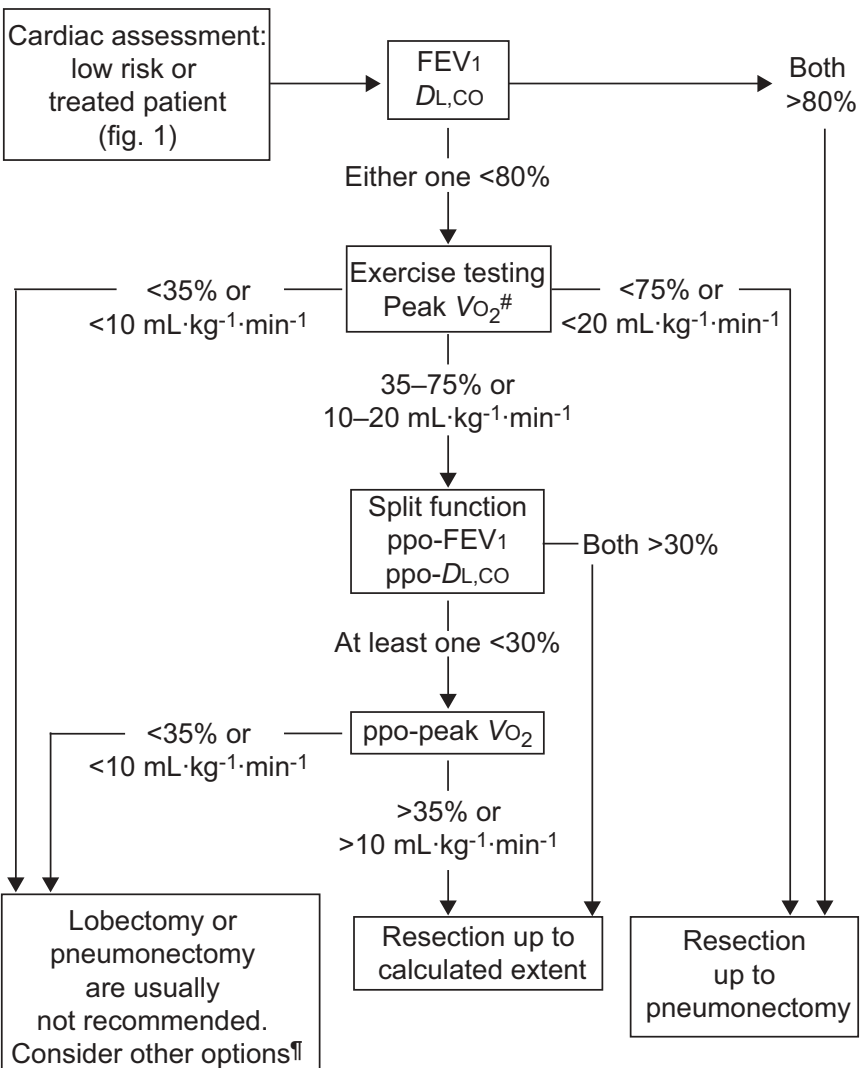

FIGURE 2. Algorithm for assessment of cardiopulmonary reserve before lung resection in lung cancer patients. $F E V_{1}$ : forced expiratory volume in $1 \mathrm{~s}$; $D\llcorner, \mathrm{CO}$ : diffusing capacity of the lung for carbon monoxide; $\mathrm{VO}_{2}$ : oxygen consumption; ppo: predicted post-operative. ${ }^{\#}$ : If peak $\mathrm{VO}_{2}$ is not available, cardiopulmonary exercise testing can be replaced by stair climbing (see subsection entitled Exercise tests); however, if altitude reaching during stair climbing is $<22 \mathrm{~m}$, cardiopulmonary exercise testing with peak $\mathrm{VO}_{2}$ measurement is highly recommended; ": see sections entitled Surgical techniques in lung cancer and Chemo-radiotherapy in lung cancer. Modified from [59], with permission from the publisher.

\section{Split function studies}

Different techniques have been used to predict post-operative lung function. These have included various pulmonary function tests and quantitative ventilation/perfusion scintigraphy [64, 87-89]. In practice, scintigraphy is not widely employed in assessing patients for lobectomy, because of the difficulty in interpreting the contribution of individual lobes to the overall ventilation or perfusion. This may explain why several investigators have reported that the simple calculation using lung segment counting can predict post-operative FEV1 as accurately as ventilation/perfusion scintigraphy [90-94].

Perfusion scintigraphy is the most widely used method to predict post-operative lung function in lung cancer patients undergoing pneumonectomy [33-34].

The reported correlation between the actual and predicted post-operative FEV1 using quantitative ventilation/perfusion scintigraphy has been variable, with correlative figures quoted between $r=0.67$ to $r=0.9 \quad[62,63,91,93,95-99]$. Either ventilation scintigraphy [99] or perfusion scintigraphy [62, $63,91]$ offer good prediction of post-operative lung function, but there seems to be no additional benefit in performing both [99]. The interpretation of the results, however, needs to take into account the fact that these techniques may underestimate the actual post-operative value $[63,93,98]$.

The following equations should be used to calculate predicted post-operative values for FEV1, DL,CO and maximal oxygen consumption $\left(V_{2}\right.$, peak $)[82,100]$, in which $\mathrm{T}$ is the total number of functioning segments before the operation; $\mathrm{R}$ is the residual number of functioning segments after the operation; $a$ is the number of unobstructed segments to be resected; and $b$ is the total number of unobstructed segments.

19 - number of obstructed segments (estimated by image techniques and/or bronchoscopy) $=\mathrm{T}$

$\mathrm{T}$ - number of functioning segments to be resected $=\mathrm{R}$

$$
\text { ppo values }=(\text { pre-operative value } / T) \times R
$$

Or, expressed in another form, ppo-FEV1 before lobectomy:

$$
\text { ppo-FEV1 }=\text { pre-operative FEV1 } \times(1-\mathrm{a} / \mathrm{b})
$$

ppo-FEV1 before pneumonectomy:

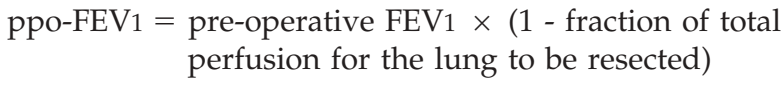

ppo-DL,CO before lobectomy:

$$
\text { ppo- } D \mathrm{~L}, \mathrm{CO}=\text { pre-operative } D \mathrm{~L}, \mathrm{CO} \times(1-\mathrm{a} / \mathrm{b})
$$

ppo-DL,CO before pneumonectomy:

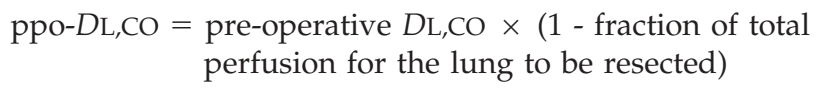

ppo- $V \mathrm{O}_{2}$, peak before lobectomy:

$$
\text { ppo- } V \mathrm{O}_{2} \text {,peak }=\text { pre-operative } V_{\mathrm{O}_{2}} \text { peak } \times(1-\mathrm{a} / \mathrm{b})
$$

ppo- $-\mathrm{OO}_{2}$,peak before pneumonectomy:

ppo- $V \mathrm{O}_{2}$,peak $=$ pre-operative $V \mathrm{O}_{2}$,peak $\times(1-$ fraction of total perfusion for the lung to be resected)

In the past years, imaging techniques have been proposed to predict post-operative pulmonary function: computed tomography (CT) scan, magnetic resonance imaging (MRI), single photon emission computed tomography (SPECT), or a combination of these [100-108]. Quantitative CT appeared to be at least as accurate as perfusion scintigraphy.

\section{Recommendations}

1) The first estimate of residual lung function should be calculated based on segment counting. Only segments not totally obstructed should be taken into account: the patency of bronchus (bronchoscopy) and segment structure (CT scan) should be preserved. Level of evidence 2+; grade of recommendations $\mathrm{C}$.

2) Patients with borderline function (fig. 2) should need imaging-based calculation of residual lung function: ventilation or perfusion scintigraphy before pneumonectomy, or quantitative CT scan (see statement 3 ) before lobectomy or pneumonectomy. Level of evidence 2+; grade of recommendations $\mathrm{C}$. 


\section{Statements}

1) Either ventilation scintigraphy or perfusion scintigraphy offer good prediction of post-operative lung function; however, there is no additional benefit in performing both. Level of evidence $2+$.

2) Apart from FEV1, DL,CO and $V_{\mathrm{O}_{2}}$,peak have been used in split function analysis and successfully included in an algorithm. Level of evidence $2+$.

3) Teams concerned with research in pre-operative evaluation before lung cancer surgery should be encouraged to use quantitative CT, MRI or SPECT. Level of evidence $2+$.

\section{Exercise tests}

Exercise tests: systematic or selective?

Exercise testing has been used for a variety of purposes, including pre-operative evaluation for patients undergoing lung resection. The aim of exercise testing is to stress the whole cardiopulmonary/systemic oxygen delivery systems and estimate the physiological reserve that may be available after surgery. During exercise, the lung experiences increases in ventilation, oxygen uptake, carbon dioxide output and blood flow similar to those observed during the post-operative period after lung resection. Therefore, a single test can be used to assess the physiological response after surgery. It is hypothesised that those patients unable to perform adequately on exercise testing may similarly to do so in response to surgical stress or adverse post-operative events and, therefore, performance on exercise testing should be correlated to surgical outcome. In fact, a recently published meta-analysis has shown that exercise capacity, expressed as $V_{\mathrm{O}_{2}}$, peak is lower in patients that develop post-operative cardiorespiratory complications after lung resection [109]. Besides early postoperative outcome, performance on exercise tests is also a better predictor of long-term exercise capacity than conventional pre-operative pulmonary function tests [64]. Nevertheless, exercise tests are usually recommended only in selected cases (unfit or reduced FEV1 and/or DL,CO) [33, 34].

Several authors [84, 110-112] have found a good correlation between low $\mathrm{VO}_{2}$,peak (per cent of predicted) and poor postoperative outcome. It is generally reported that a value $<50$ $60 \%$ pred increases the surgical mortality risk. In a prospective evaluation of an algorithm for functional assessment of lung resection candidates, measurement of $\mathrm{VO}_{2}$,peak was performed in all patients with an FEV1 and/or DL,CO value $<80 \%$ [112]. Patients having a $V \mathrm{O}_{2}$, peak $>20 \mathrm{~mL} \cdot \mathrm{kg}^{-1} \cdot \mathrm{min}^{-1}$ or $>75 \%$ pred were deemed operable, while in cases with a $V_{\mathrm{O}_{2}}$,peak $<40 \%$ or $<10 \mathrm{~mL} \cdot \mathrm{kg}^{-1} \cdot \mathrm{min}^{-1}$ surgical therapy was contraindicated. Between both values, post-operative FEV1 and DL,CO were estimated and, in those cases having either one $>40 \%$ and ppo$V_{\mathrm{O}_{2}}$,peak $<35 \%$ and $>10 \mathrm{~mL} \cdot \mathrm{kg}^{-1} \cdot \mathrm{min}^{-1}$, surgical resection was performed. The authors communicated a decrease in overall hospital mortality compared to historical controls.

Recently, LOEWEN et al. [84] have reported that patients who had a $V_{2}$,peak $<65 \%$ (or $<16 \mathrm{~mL} \cdot \mathrm{kg}^{-1} \cdot \mathrm{min}^{-1}$ ) were more likely to suffer complications, and BRUNELLI et al. [113] found that all deaths after lung resection occurred in patients with a $V_{\mathrm{O}_{2}}$,peak $<20 \mathrm{~mL} \cdot \mathrm{kg}^{-1} \cdot \mathrm{min}^{-1}$.

\section{Recommendation}

Exercise tests should be indicated in all patients undergoing surgery for lung cancer with FEV1 or DL,CO $<80 \%$ of normal values. Level of evidence $2++$; grade of recommendation $\mathrm{B}$.

\section{Low-technology exercise: stair, 6-min walk distance or shuttle?}

Aside from pulmonary function tests, other measures of cardiopulmonary fitness have been shown to be useful for pre-operative risk stratification. The most widely used lowtechnology tests include 6-min walking, shuttle walk test and stair climbing.

Although distance walked in 6-12 min has been shown to be highly reliable in estimating $V_{\mathrm{O}}$,peak in healthy subjects [114], COPD patients [115] and transplant candidates [116], nonunivocal findings have been published regarding its association with post-operative outcome after lung resection [36-38, 117].

The shuttle walk test has been reported to be more

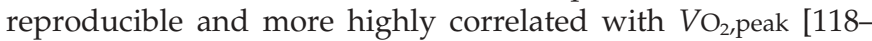
120]. It has been estimated by regression analysis that 25 shuttles on the shuttle walk test indicate a $V \mathrm{O}_{2}$,peak of $10 \mathrm{~mL} \cdot \mathrm{kg}^{-1} \cdot \mathrm{min}^{-1}$ [119] and, therefore, this cut-off value has been suggested in the functional algorithm proposed by the British Thoracic Society [33].

However, WIN and co-workers [121, 122] found no statistically significant difference in shuttle walk distance between patients with and without complications after lung resection. They also found that this test tends to underestimate exercise capacity at the lower range compared with $V_{\mathrm{O}_{2}}$, peak, concluding that it should not be used alone to exclude patients from operation, contrary to current recommendations [33]. The same authors found that all patients who walked $>400 \mathrm{~m}$ at shuttle walk test had a $V_{2}$, peak $>15 \mathrm{~mL} \cdot \mathrm{kg}^{-1} \cdot \mathrm{min}^{-1}$ [33].

Several papers have shown the effectiveness of the stair climbing test to predict major cardiopulmonary complications after lung resection [36, 123, 124]. In a more recent study, BRUNELLI et al. [125] confirmed his previous findings in a series of 640 patients submitted to major lung resection. Patients climbing $<12 \mathrm{~m}$ had two-fold and 13-fold higher rates of complications and mortality compared to those climbing $>22 \mathrm{~m}(<1 \%$ mortality rate). In this latter paper, they found that, even in patients with ppo-FEV1 and/or ppo-DL,CO $<40 \%$, the mortality rate in those climbing $>22 \mathrm{~m}$ was zero.

Although exercise oximetry has been proposed to be a useful tool in the pre-operative functional evaluation of lung resection candidates [33, 34], the role of exercise oxygen desaturation (EOD) in risk stratification has not been defined regarding its definition and its association with early outcome after lung resection [126-128].

Two studies [126, 127] found that EOD was a better discriminant of post-operative respiratory failure, need for intensive care unit (ICU) admission, prolonged hospital stay and home oxygen requirement with respect to spirometry. However, VARELA et al. [128] found that oxygen desaturation $<90 \%$ during standardised incremental cycle ergometry was not a significant predictor of post-operative cardiopulmonary morbidity. Recently, BRUNELLI et al. [129] found that a 
desaturation $>4 \%$ was significantly associated with postoperative complications, even after adjusting its effect for other factors with regression analysis.

\section{Recommendations}

1) Shuttle walk test distance underestimates exercise capacity at the lower range and was not found to discriminate between patients with and without complications. Thus, it should not be used alone to select patients for operation. It could be used as a screening test: patients walking $<400 \mathrm{~m}$ may have $V \mathrm{O}_{2}$,peak $<15 \mathrm{~mL} \cdot \mathrm{kg}^{-1} \cdot \mathrm{min}^{-1}$. Level of evidence $2+$; grade of recommendation $\mathrm{C}$.

2) Standardised symptom-limited stair climbing test is a costeffective test capable of predicting morbidity and mortality after lung resection better than traditional spirometry values. It should be used as a first-line functional screening test to select those patients that can undergo safely to operation (height of ascent $>22 \mathrm{~m}$ ) or those who need more sophisticated exercise tests (compare with the following subsection entitled The role of cardiopulmonary exercise tests) in order to optimise their peri-operative management. Level of evidence 2++; grade of recommendation $\mathrm{B}$.

3) The 6-min walk test should not be used to select patients for operation. Level of evidence 2+; grade of recommendation C.

\section{Statement}

Patients with EOD $>4 \%$ (arterial oxygen saturation measured by pulse oximetry, measured using correct methodology) during stair climbing may have an increased rate of complications and mortality after lung resection. They need, therefore, to be further assessed with formal cardiopulmonary exercise testing (CPET) for a more precise evaluation of their cardiopulmonary system in order to optimise their perioperative management. Level of evidence $2+$.

\section{The role of cardiopulmonary exercise testing}

In high-technology exercise testing, or CPET, maximal or symptom-limited exercise is performed, usually on a bicycle or treadmill. CPET is performed in a controlled environment with continuous monitoring of various parameters; it ensures easy standardisation and good reproducibility of results. $V_{2}$, peak is the single most important parameter as a direct measure of exercise capacity. CPET not only allows assessment of overall cardiopulmonary reserves but, in case of a limitation of exercise capacity, also to find the reason for this, such as pulmonary, cardiovascular or musculoskeletal limitations. If a particular organ system can be incriminated as the limiting factor, specific treatment options can be of benefit, such as optimisation of COPD treatment or management of ischaemic heart disease.

Various cut-off values of $V_{2}$,peak expressed either in $\mathrm{mL} \cdot \mathrm{kg}^{-1} \cdot \mathrm{min}^{-1}$ and/or in per cent of predicted values have been suggested, which indicate whether patients can safely undergo pulmonary resections, and most importantly estimate the extent of resection possible [35, 44, 84, 110-112, 130-134]. There is currently wide consensus that values of $V_{\mathrm{O}_{2}}$,peak $>20 \mathrm{~mL} \cdot \mathrm{kg}^{-1} \cdot \mathrm{min}^{-1}$ qualify for resection up to pneumonectomy, whereas values $<10 \mathrm{~mL} \cdot \mathrm{kg}^{-1} \cdot \mathrm{min}^{-1}$ indicate high risk for any resection. Expressed as per cent of predicted the respective values are $>75 \%$ and $<40 \%$ pred. A further suggestion is the use of predicted post-operative values for $\mathrm{VO}_{2}$,peak based on a very high mortality, with ppo- $V \mathrm{O}_{2}$, peak values of $<10 \mathrm{~mL} \cdot \mathrm{kg}^{-1} \cdot \mathrm{min}^{-1}(35 \%$ pred) [131]. See also the corresponding paragraph in the subsection entitled Split function.

CPET should be performed according to the published ATS guidelines [135].

\section{Recommendations}

1) CPET is performed in controlled environment, and is reproducible and safe. $\mathrm{VO}_{2}$, peak measured during an incremental exercise on treadmill or cycle should be regarded as the most important parameter to consider, as a measure of exercise capacity and as highly predictive of post-operative complications. Level of evidence 2++; grade of recommendation B.

2) The following basic cut-off values for $V_{2}$,peak should be considered: $>75 \%$ pred or $>20 \mathrm{~mL} \cdot \mathrm{kg}^{-1} \cdot \mathrm{min}^{-1}$ qualifies for pneumonectomy; $<35 \%$ pred or $<10 \mathrm{~mL} \cdot \mathrm{kg}^{-1} \cdot \mathrm{min}^{-1}$ indicates high risk for any resection. Evidence is not sufficient to recommend cut-off values for lobectomy. Level of evidence $2++$; grade of recommendation $\mathrm{C}$.

\section{Future trends in pre-operative work-up}

Evaluation of pre-operative daily physical activity

The inclusion of some simple inexpensive parameters in the pre-operative work-up could result in better knowledge of the patient performance status. According to MANINI et al. [136], daily living energy expenditure was strongly associated with lower risk of operative mortality. Motion detectors (pedometers) are considered useful for measuring daily activity, which is related to physiological impairment due to COPD and other diseases [137, 138], and its usefulness to predict postoperative outcome should be tested.

\section{DL, co during exercise}

The lung has a large reserve of diffusing capacity that can be recruited as oxygen demand increases. WANG et al. [139] found, in 57 patients, that the increase in DL,CO from rest to $70 \%$ of maximal workload was the best pre-operative predictor of post-operative complications, followed by $\mathrm{VO}_{2}$,peak measurement.

\section{Statements}

1) Evaluation of daily physical activity could replace, or be complementary to, sophisticated pre-operative exercise tests. Level of evidence 2.

2) Although it is not easily available and needs confirmation in larger series, exercise $D \mathrm{~L}, \mathrm{CO}$ may be an interesting parameter to investigate since its impairment reflects poor recruitment of pulmonary capillary and, to a lesser extent, alveolar volume. Level of evidence 2.

\section{PATIENT CARE MANAGEMENT The role of rehabilitation before and after lung resection surgery}

Adverse events after lung resection are limited [140], but a considerable proportion of patients suffer from significant late complications [141]. Pulmonary rehabilitation, including exercise and education, is effective in respiratory patients with disability [142-144], in candidates for lung volume reduction 
$[145,146]$ and in the pre-post lung transplantation $[147,148]$ while it is not clearly indicated in surgical patients with lung cancer.

Notwithstanding, pre-operative $V_{\mathrm{O}_{2}}$ is inversely related to the probability of complications after lung resection [109], which, in turn, is associated with post-operative loss of function [54, 149]. Therefore, it seems rational to hypothesise that pulmonary rehabilitation could decrease the rate of adverse events.

Chest physiotherapy was found to be more effective than incentive spirometry in reducing the rate of pulmonary atelectasis after lobectomy [150]. Pre-operative inspiratory muscle training may decrease the prevalence of late complications after cardiac surgery [151].

Comprehensive pulmonary rehabilitation was able to improve $\mathrm{VO}_{2}$ rate before surgery in COPD patients with low $\mathrm{VO}_{2}$ $\left(<15 \mathrm{~mL} \cdot \mathrm{kg}^{-1} \cdot \mathrm{min}^{-1}\right)$, thus reducing late complications and not influencing operability and prognosis [152].

Pre-operative training programmes have led to a reduction of hospital stay and complications in COPD patients with lung cancer [153]; however, improved accessibility to intervention was found only in treated patients with "quasi normal" respiratory function [154]. Specific programmes that include smoking cessation periods before surgery may change smoking behaviour and positively impact on the risk of complications [155].

The effectiveness of comprehensive inpatient pulmonary rehabilitation has shown benefits indicating that both functional exercise capacity [156] and lung volumes [157] may improve in treated individuals but not in controls.

In light of the limited data underlining the evidence-based benefits of a pre- or post-operative rehabilitation in lung resection candidates [158-160], future research on programme content and duration of pulmonary rehabilitation should be considered priorities.

Pulmonary rehabilitation should be performed according to published guidelines [161].

\section{Recommendations}

1) Smoking cessation of sufficient duration (2-4 weeks) before surgery should be recommended, since it may change the smoking behaviour peri-operatively and decrease post-operative complications. Level of evidence 2+; grade of recommendation B.

2) Early pre- and post-operative rehabilitation should be recommended, since it may produce functional benefits in resectable lung cancer patients. Candidate selection, late outcomes (i.e. post-operative complications and death), and programme content and duration need to be further investigated. Level of evidence 2+; grade of recommendation C.

\section{Statement}

Pre-operative exercise capacity is inversely related to morbidity after lung resection. Level of evidence 1+.

Scoring systems: do they have a place in patient selection? Effective scoring systems predict the likelihood of selected outcomes in groups of patients, enabling risk stratification. The
Charlson comorbidity index, Kaplan-Feinstein index, American Society of Anesthesiologists score, and the physiological and operative severity score (POSSUM), perform better than individual risk factors and have intermediate power to predict peri-operative mortality and morbidity after lung resection (area under the curve (AUC) <0.7) [162-167]. Scoring systems specific for lung resection have been developed, including the cardiopulmonary risk index (CPRI), the predictive respiratory quotient (equal to (ppo-FEV $1 \times(\mathrm{ppo}-$ $\left.D \mathrm{~L}, \mathrm{CO})^{2}\right) /($ alveolar-arterial oxygen tension difference)) the post-operative pulmonary product (equal to ppo-FEV $1 \times$ ppoDL,CO), and the EVAD system (age, FEV1, DL,CO) [38, 168-170]. The first three fall short either because they most simply dichotomise outcomes, making detailed predictions impossible, or are insufficiently accurate in predicting risk for individuals. EVAD, although its performance equaled or exceeded that of CPRI and POSSUM, was insufficient to assign individual risks accurately (AUC 0.64).

The National Veterans Affairs Surgical Quality Improvement Program (NVASQIP), consisting of $>3,500$ patients, identified nine independent risk factors for bad peri-operative outcomes [171] with acceptable prediction for mortality and morbidity (AUCs of 0.72 and 0.62, respectively). The ESTS Subjective and Objective Scores did not appear accurate at the extremes of risk [83]. In the Thorascore system, nine variables emerged as being significant in the predictive model, with an AUC of 0.86 and a correlation between observed and expected mortality of 0.99 [172]. Some models have been used to assess long-term survival, including the Charlson comorbidity index, the Kaplan-Feinstein index, and the Thorascore system [163, 167, 173-177]. These do not include tumour stage, and so are less relevant for selecting patients for major lung resection for cancer therapy.

Although lacking accuracy for assigning specific risk for individual patients, models incorporating functional characteristics, comorbidity factors, and surgical variables (NVASQIP and Thoracoscore) are valid and useful tools for predicting relative operative death or major cardiopulmonary complications in groups of patients. 5-yr survival following lung cancer resection is better predicted by scoring systems including comorbidity indices and tumour stage.

\section{Recommendation}

The current standard of care should not require the use of scoring systems for adequate evaluation of individual patients for lung resection. However, these tools should be considered as useful instruments for benchmarking and risk stratification among groups of surgical candidates. Level of evidence 2++; grade of recommendation $\mathrm{B}$.

\section{Do we need to send all thoracotomies to the ICU?}

Within the first five post-operative days, cardiopulmonary complications occur in as many as $15-40 \%$ of patients and markedly prolong the hospital stay [140, 178-182]. Accordingly, implementation of evidence-based medical strategies as well as monitoring and treatment of high-risk patients in dedicated care units are aimed at improving the postoperative outcome while limiting healthcare expenses [183, 184]. 




\#: according to [185]. COPD: chronic obstructive pulmonary disease; FEV1: forced expiratory volume in $1 \mathrm{~s}$; MELD: model for end-stage liver disease; $\mathrm{VO}_{2}$ : oxygen consumption

Two distinct patterns of clinical pathways have been reported: 1) routine ICU admission of operated patients (30-100\%) providing precautionary cardiopulmonary monitoring and assistance by highly qualified healthcare personnel; 2) selective ICU admission only for ventilatory support and/or on an

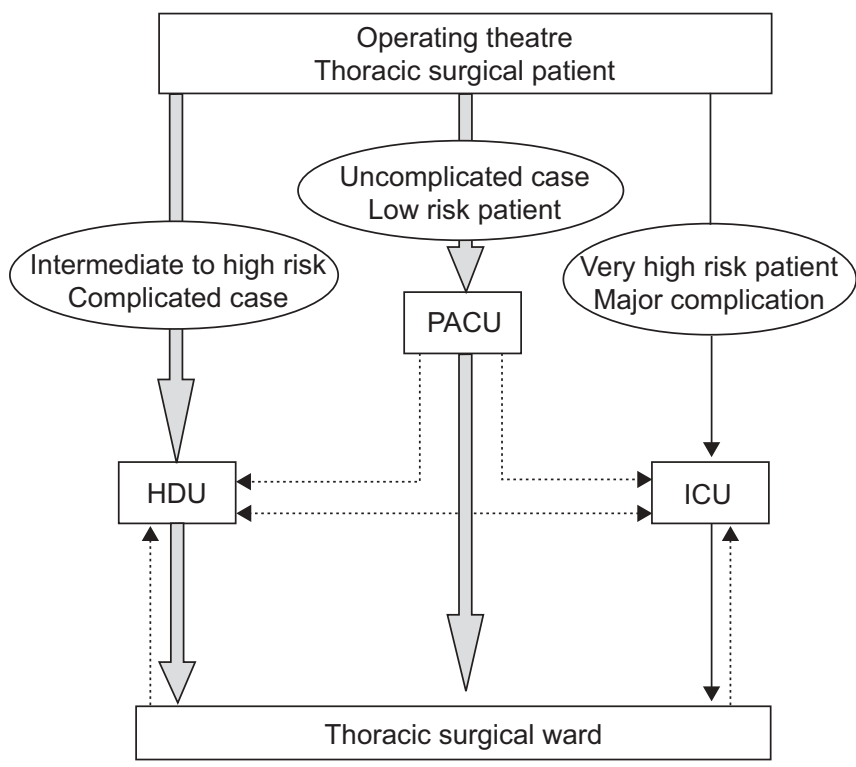

FIGURE 3. Clinical pathways for admission (and discharge) to (and from) the high dependency unit (HDU), intensive care unit (ICU) and thoracic surgical ward. PACU: post-anaesthesia care unit. emergency basis, due to major peri-operative complications, while the majority of patients are transferred to the surgical ward either after a short 2-4 h stay in the post-anaesthesia care unit (for uncomplicated cases and low-risk patients) or after a 12-36 h stay in a high-dependency unit (HDU; for higher risk cases, see table 3).

The tendency to "over-admit" patients to the ICU may result in inappropriate bed occupation, raising hospital costs, delaying patient's mobilisation and increasing risk of nosocomial infections [186]. The HDU offers a higher level of care than in the ward (i.e. nurse:patient ratio 1:2) with provision of cardiopulmonary monitoring and noninvasive ventilation modalities, as well as drug haemodynamic support [187, 188].

No randomised controlled trials have compared the outcome and treatment costs in similar thoracic surgical patients admitted either to the ICU, HDU or surgical wards. However, observational studies have demonstrated the appropriateness and advantages of the HDU as reflected by low mortality and morbidity rates (2-3\% and $10-20 \%$, respectively) while the admission rate to ICU remained $<2 \%[169,188-191]$.

In an effort to improve patient outcome and optimise hospital resource utilisation, clinical pathways should be proposed for admission (and discharge) to (and from) HDU, ICU and surgical wards (fig. 3).

\section{Recommendations}

1) A systematic admission to ICU after thoracotomy should not be recommended. Level of evidence $2++$; grade of recommendation $\mathrm{C}$.

2) In the presence of an appropriate HDU, nobody should be admitted to ICU on an elective basis. On an emergency basis, those patients requiring support for organ failure (i.e. ventilatory mechanical assistance) should be admitted to ICU. Level of evidence 2+; grade of recommendation C.

3) Patients undergoing complex pulmonary resection, those with marginal cardiopulmonary reserve and those with moderate to high risk according to table 3 should be admitted to HDU. Level of evidence 2++; grade of recommendation C.

4) After surgery, low-risk patients should be sent to a dedicated thoracic surgical unit, and not to a general surgical ward. Level of evidence 2++; grade of recommendation B.

\section{Residual function and QoL after radical treatment}

Many studies have shown that after lobectomy there is a disproportionate functional early loss with a gradual recovery in the following months. The residual function (FEV1, DL,CO and $\mathrm{VO}_{2}$, peak) may reach values as high as $90-95 \%$ of preoperative values 3-6 months after operation. Conversely, after pneumonectomy, the loss in pulmonary function and exercise capacity is larger (20-30\% at 6 months) and substantially stable over time [54, 64, 65, 192-195]. In general, exercise tolerance displays a more complete recovery compared to airflow and gas exchange capacities, presumably due to other compensatory mechanisms related to the cardiovascular system and the peripheral oxygen extraction capacity [54, 64, 194].

Most lung cancer patients are psychologically depressed and exhibit an increased tension-anxiety status compared with the 
general population before being submitted to operation [196199].

BRUNELLI et al. [197] found that, compared with the general population, candidates for lung resection with lung cancer had physical and psychosocial dysfunction: reduced preoperative values of role limitation caused by physical problems, general health perception, social functioning, role limitation caused by emotional problems and mental health perception scales. Many of the altered scales remained below 50 (general population mean) even 3 months after operation.

Several studies have shown that lung resection determines a transient worsening of QoL 1 month following the operation with most of the scales returning to pre-operative values after 3-6 months [196-199]. An exception to this trend is represented by pneumonectomy patients that display a persistent deterioration of physiological and mental QoL scales even 36 months after operation [197, 198].

Perhaps with the exception of DL,CO [199], objective measures of cardiorespiratory function have not been found to correlate well with patients' perceived QoL [64, 192]. In this regard, patients' perception of symptoms, like dyspnoea and postthoracotomy pain, appear more important to QoL [200]. Thus, an ad hoc QoL instrument should always be used for QoL evaluation.

Interestingly, in elderly patients and in those traditionally deemed at increased surgical risk, the post-operative physiological or mental status did not differ from those of lower risk counterparts [197, 201, 202]. These findings may have great importance during patient counselling before the operation. Particularly in patients deemed to be at higher risk for major post-operative cardiopulmonary complications, the information that residual QoL will be similar to the one experienced by younger and fitter patients may help in their decision to proceed with surgery.

QoL has been uncommonly regarded as a primary goal of chemotherapy trials [203, 204]. Moreover, between-trials comparison remains difficult because of heterogeneous QoL reporting and analysis techniques. Nevertheless, improvement in various scales of QoL has been reported in a number of clinical trials. Compared with best supportive care, chemotherapy offers symptom control, not only in patients with objective response to chemotherapy, but also in a proportion of those with disease stabilisation. Symptom palliation correlates well with QoL.

\section{Recommendation}

Specific QoL instruments should always be used for QoL evaluation. Level of evidence 2++; grade of recommendation B.

\section{Statement}

Pulmonary function assessment alone has been a poor predictor of the perceived residual QoL. Perception of symptoms has been reported to be more important to QoL, implying the need for monitoring respiratory symptoms after thoracotomy or chemotherapy. Level of evidence $2+$.

\section{SURGICAL TECHNIQUES IN LUNG CANCER Combined cancer surgery and lung volume reduction surgery}

Lung volume reduction surgery (LVRS) has emerged as a palliative treatment for severe emphysema [205-207]. Randomised trials and observational studies have demonstrated better health status and lung function outcomes in favour of LVRS compared with usual medical care including a rehabilitation programme [208, 209]. A subgroup of patients with upper lobe emphysema appeared to be the ideal candidates, LVRS producing significant improvement in exercise capacity with better survival [210, 211]. Several case series and post hoc analysis of hospital registries have indicated acceptable operative death rate and cardiopulmonary morbidity following LVRS in patients with solitary nodules and extremely poor lung function [212-218].

After anatomical lobectomy, patients with normal or mildly diseased lungs have the greatest post-operative decrease in FEV1, whereas those with poor baseline function present minimal change or even improvement in post-operative FEV1 [48-52, 54, 55, 57, 219-223]. Among 188 patients, KusHIBE et al. [224] reported that upper lobectomy but not lower lobectomy produced a "volume reduction" effect. In contrast, SEKINE et al. [55] identified COPD and pulmonary resection of the lower portion of the lung (lower or middle-lower lobectomies) as independent factors for the minimal deterioration of FEV1.

Acceptable peri-operative mortality rate (0-6\%) with prolonged cancer-free interval and sustained functional improvement (up to $1 \mathrm{yr}$ ) have been reported in selected patients with pre-operative FEV1 <60\% [49, 212, 219, 223, 225]. Although long-term survival after lobar LVRS for stage I lung cancer is limited by physiological rather than oncological factors, outcomes are still better than those reported for any other modality of treatment.

Accurate estimation of post-operative pulmonary function should take into account the effect of deflating the overexpanded thorax and reinflating perfused lung areas. Quantitative imaging techniques may give useful information in this regard [105].

Consideration of fitness for surgery should acknowledge the effects of lobar LVRS in patients with severe COPD and early lung cancer stages: resecting a hyperinflated and poorly perfused tumour-containing lobe can outweigh any loss of function as well as the risks of major adverse events. In these selected high-risk patients, anatomical lobectomy, occasionally combined with LVRS has been shown to produce beneficial effects in terms of chest wall mechanics and lung elastic recoil, as well as survival.

\section{Recommendation}

Anatomical lobectomy with or without complementary LVRS should be performed in well-selected COPD patients with lung cancer. Level of evidence 2++; grade of recommendation $\mathrm{B}$.

\section{Compromised parenchymal sparing resections and minimally invasive techniques: the balance between oncological radicality and functional reserve}

Parenchymal sparing resections, also called sublobar resections, include segmentectomy and wedge resections. 


\section{The Lung Cancer Study Group randomised trial}

The Lung Cancer Study Group (LCSG) randomised trial, performed in patients with adequate lung function and limited resection, including wedge resections (one-third of patients) and segmental resections (two thirds), showed a $75 \%$ increase in recurrence compared with lobectomy (38 out of 122 versus 23 out of 125), attributable to an observed tripling of local recurrence rate (21 out of 122 versus eight out of 125). Segmentectomy had a lower locoregional recurrence risk than wedge: 0.022 for lobectomy, 0.044 for segmentectomy and 0.086 for wedge resections (rate per person per year) [226].

\section{Lobectomy versus segmentectomy}

Retrospective [227-230] and case-control [231] studies provide similar results for small tumours (stage IA $<2$ or $3 \mathrm{~cm}$ ). Local recurrence after segmentectomy appears influenced by segment localisation and width of resection [232]. In good risk patients, segmentectomy is associated with slightly better pulmonary function $[233,234]$.

In patients with poor lung function, anatomical segmentectomy allows resections of stage I without compromising survival and with acceptable lung function preservation [235].

\section{Wedge resection versus lobectomy}

A few retrospective studies have reported contradictory results: increased risk of local recurrence in case of wedge resection [226], better survival with lobectomy [236] or similar results [237].

\section{Segmentectomy versus wedge resection}

There were fewer locoregional recurrences with segmentectomy in the LCSG trial [226], increased cancer-related survival in a retrospective study in stage IA [238] but significantly decreased survival with wedge resection for tumour of size 2$3 \mathrm{~cm}$ in a Japanese trial [228].

\section{Sublobar resection}

Some authors do not report data by separating interventions according to wedge or segmental resections, using the term "sublobar" or limited resection [239, 240]. If the trend in those series is shorter survival in comparison to classical lobectomy, a meta-analysis failed to show significant survival difference in stage I NSCLC [241].

\section{Small peripheral adenocarcinoma}

For a tumour $<2 \mathrm{~cm}$, wedge resection appeared to be associated with similar results in terms of survival or of cancer-specific survival, whatever the type of surgery performed [228] and with excellent results for small adenocarcinoma with an air-containing image on high-resolution CT scan [241].

\section{Lung resection after prior lobectomy}

Limited resection after prior lobectomy is associated with decreased and acceptable post-operative morbidity and mortality [242].

\section{Recommendations}

Anatomical segmentectomy could be recommended in the following situations.
1) Stage IA (tumour size $2-3 \mathrm{~cm}$ ) with margins of resection $>1 \mathrm{~cm}$. Level of evidence 2 ; grade of recommendation D.

2) Stage I in patients with poor lung function. Level of evidence 2; grade of recommendation $\mathrm{D}$.

3) Lung resection after prior lobectomy. Level of evidence 2; grade of recommendation D.

Wedge resection could be recommended in the following situations.

1) Stage IA (tumour size $<2 \mathrm{~cm}$ ). Level of evidence 2; grade of recommendation $\mathrm{D}$.

2) Small peripheral adenocarcinoma with an air-containing image (ground glass opacity) on high-resolution CT scan. Level of evidence 2; grade of recommendation D.

\section{CHEMO-RADIOTHERAPY IN LUNG CANCER Neoadjuvant chemotherapy and complications}

Neoadjuvant chemotherapy in lung cancer patients may have several advantages: 1) more efficacious distribution of the chemotherapeutic agent prior to surgical manipulation; 2) in vivo testing of the chemotherapeutic agent; 3) follow-up not hindered by the residual effects of chemo- or radiotherapy administered after surgery.

According to the above, all resectable and operable lung cancer stages have been, and currently are, the subject of trials of neoadjuvant treatments, despite two major potential drawbacks: the delay of treatment of the primary lung tumour, especially for traditionally "surgical" subsets, like stage I and II nonsmall cell lung cancer (NSCLC); and the suggested increase in mortality and morbidity rates.

The evidence from randomised phase III trials indicates improved resectability after chemotherapy and suggests a marginal survival advantage for the induction arms [243, 244].

Several studies have addressed the issue of post-operative mortality and morbidity following induction treatment. Significant overall morbidity $(>40 \%)$ and mortality rates have been reported after pneumonectomy. In particular, right pneumonectomy after induction treatment may entail mortality rates of up to $26 \%[182,245-248]$.

\section{Risk of induction chemotherapy in surgery with an extent of less} than pneumonectomy

Despite the absence of randomised trials having as end-point the impact of chemotherapy on the post-operative outcome of resections less than pneumonectomy, recent evidence resulting from retrospective and prospective studies [249-254] has shown acceptable morbidity and mortality rates in selected patients.

\section{Risk of induction chemotherapy in pneumonectomy}

In the most recently published randomised controlled trials of neoadjuvant chemotherapy [255-257], the concern that has arisen from the previously reported worrying mortality and morbidity rates, especially after right pneumonectomy, is mitigated by the available results, with the only exception of 
the Spanish trial confirming a $30 \%$ mortality rate for right pneumonectomy following induction chemotherapy [258].

\section{Risk of combined induction chemo- and radiotherapy}

Induction chemo-radiotherapy may indeed be a prelude to significant morbidity and mortality [258-260], although recent evidence from institutional studies shows increased safety in adding radiotherapy to chemotherapy induction regimens [261-264]. A prospective randomised trial powered on postoperative morbidity and mortality is needed to compare chemotherapy versus chemo-radiotherapy followed by surgery to clarify this issue.

In all of the above mentioned trials, patients who were not considered to be fit for the multimodal treatment were inelegible. The reported complications occurred, thus, in "fit" patients.

Effects of radiotherapy and chemotherapy on pulmonary function Radiotherapy of the lung may cause radiation pneumonitis, usually several weeks after the end of radiotherapy. In patients with lung cancer, clinical pneumonitis can occur in 5-15\% of patients, while radiographic abnormalities may be present in $\sim 60 \%$ [265]. Certain chemotherapeutic drugs, which are frequently used for treating lung cancer, like taxanes and gemcitabine, can cause adverse reactions in the lungs with loss of function [266-269].

Furthermore, several chemotherapeutic agents are known sensitisers to radiotherapy, including, among others, doxorubicin, taxanes, mitomycine, vinorelbine, gemcitabine and platinum derivatives. Patients receiving these drugs are at a higher risk of developing radiation-induced lung injury, if administered at full dosages.

\section{Recommendation}

After induction chemotherapy and/or radiotherapy a new functional evaluation (particularly of $D \mathrm{~L}, \mathrm{CO}$ ) before surgery should be recommended. Level of evidence 2+; grade of recommendation $\mathrm{C}$.

\section{Statements}

1) The addition of induction chemotherapy to surgical resection less than pneumonectomy does not significantly increase morbidity and mortality. Level of evidence 1.

2) The addition of induction chemotherapy to surgical resection increases mortality after pneumonectomy. Level of evidence 1 .

3) The addition of radiotherapy to neoadjuvant chemotherapy followed by pneumonectomy increases mortality. Level of evidence 1 .

4) The addition of induction chemotherapy to right pneumonectomy increases morbidity and mortality. Level of evidence 1.

5) The addition of induction chemotherapy to resection, especially pneumonectomy, increases the risk for post-operative acute respiratory distress syndrome and respiratory failure. Level of evidence 1.

\section{Definitive radiotherapy and chemotherapy: functional selection criteria and definition of risk. Should surgical criteria be re-calibrated for radiotherapy and chemotherapy?}

Radiotherapy

The greatest limitation to definitive radiotherapy, apart from acute oesophagitis, is radiotherapy-induced lung toxicity [270]. It has to be emphasised that the comparison of studies on this topic is complex due to considerable heterogeneity in the scoring systems used in the literature to grade radiotherapyinduced lung toxicity.

It is generally assumed that patients with pre-existing pulmonary disease, particularly COPD, are at increased risk of radiation morbidity [271, 272] but the data relating premorbid physiology to radiation toxicity are limited. Knowledge of the risks of radiotherapy is usually used to guide the design of the radiotherapy treatment plans, rather than to decide whether or not to treat [273]. However, in many chemo-radiotherapy trials pulmonary function limits, similar to the limits used in surgical series, are set for exclusion of patients.

In the published studies not exclusively based on lung cancer patients, low arterial oxygen tension value $(<80 \mathrm{mmHg})$ [274] and low DL,CO [275-278] have been associated with increased lung toxicity and morbidity. Low FEV1 was associated with radiation pneumonitis in some $[279,280]$ but not all [281] studies. Moreover, in patients with FEV1 $<50 \%$ pred, half of the patients demonstrated a small improvement in lung function [282]. In another study, patients in whom lung perfusion was $<35 \%$ in the zones at risk tended not to have significantly decreased transfer factor during follow up [275]. A model including mean lung dose, sum of predicted perfusion reduction based on regional dose-response curve and pre-radiation pneumonitis DL,CO could not segregate patients at high risk versus those at low risk for radiation pneumonitis [283]. The risk of developing radiation pneumonitis-induced lung toxicity can be estimated by calculating the dose-volume histogram of the lungs, including $\mathrm{V}_{20}$ and mean lung dose (MLD) [284, 285].

\section{Recommendation}

Dose-volume histograms of the lung should be calculated (including $\mathrm{V}_{20}$ and MLD) to evaluate the risk of radiationinduced pulmonary toxicity. Level of evidence 2+; grade of recommendation $\mathrm{C}$.

\section{Statements}

1) Pulmonary physiology cannot accurately determine the acute and long-term risks related to thoracic radiotherapy. Level of evidence $2+$.

2) Safe lower limits of respiratory function (FEV1 or DL,CO) for radical radiotherapy have not been defined as they have been for surgery. The current evidence base does not permit any statements about what is safe or unsafe. Level of evidence $2++$.

3) To date, radiotherapy dosimetric parameters are the most effective tools for predicting radiation-related lung damage [285-287]. Models based on combination of radiotherapy planning parameters, lung function tests, and lung perfusion imaging may have a higher predictive value and should be 
addressed in further research. Biological markers predicting the risk of radiation-related lung damage should be explored further [288]. In addition, comprehensive lung function testing before and after radiotherapy, as well as the long-term effects of chemo-radiotherapy, including QoL, should be evaluated in each prospective chemo-radiotherapy trial.

\section{Chemotherapy}

The results of a meta-analysis published in 1995 based on 9,387 patients with NSCLC from randomised clinical trials supported the addition of cisplatin-containing chemotherapy regimens to thoracic radiotherapy [289]. Subsequently, the NSCLC Collaborative Group meta-analysis showed a significant survival advantage with concurrent chemo- and radiotherapy compared with sequential chemo- and radiotherapy [290].

Very few data have been reported on pre- and postchemotherapy lung and cardiac function in NSCLC treated by definitive chemo-radiotherapy. Safe lower limits of respiratory function for chemotherapy or concurrent chemo- and radiotherapy have not been defined. The only available data are the observed toxicity in patients without significant comorbidity, as usually selected in chemotherapy-based trials [291-295]. The current evidence does not permit any recommendation for treatment security.

\section{Statement}

Safe lower limits of respiratory function (FEV1 or DL,CO) for radical chemotherapy have not been defined as they have for surgery. The current evidence base does not permit any formal recommendation about what is safe or unsafe. Level of evidence $2++$.

\section{The patient at prohibitive surgical risk: alternatives to surgery \\ Radiotherapy}

A Cochrane review included 2,003 patients with medically inoperable stage I/IIa treated with radical radiotherapy [296]. Cancer-specific survival was $13-39 \%$ at 5 yrs. Local failure rates were $6-70 \%$. Radical radiotherapy appeared to result in a better survival than might be expected had treatment not been given. An optimal dose and treatment technique could not be defined.

The CHART (continuous, hyperfractionated, accelerated radiotherapy) trial randomised 563 patients with stage I-IIIB NSCLC (including 203 patients with stage I-II) to receive either CHART or conventionally fractionated radiotherapy. CHART improved 2-yr survival from $20 \%$ to $29 \%$ [297].

Conformal three-dimensional radiotherapy improves on conventional two-dimensional radiotherapy by optimising target coverage and by reducing the exposure of normal tissues to high-dose radiation [298]. The European Organization for Research and Treatment of Cancer (EORTC) guidelines for treatment planning of high-dose radiotherapy in lung cancer advocates the use of three-dimensional radiotherapy planning [299].

Hypofractionated radiotherapy has been investigated but the evidence to support the use of large fraction size is limited $[300,301]$.
Dose escalation studies investigating doses $>60$ Gy have not established an optimal radiotherapy dose, achieving a balance between local control and side effects [302-304].

Increased LC rates of $80-98 \%$ at $2-5$ yrs with overall survival of $52-83 \%$ at $2-5$ yrs [305-310] have been reported with hypofractionated stereotactic radiotherapy in stage I and II NSCLC. A variety of doses and fractionations have been used [305-315]. Treatment of tumours adjacent to a primary or secondary bronchus should be avoided as excessive acute toxicity and symptomatic bronchial stenosis have been reported [309, 313, 316].

\section{Radiofrequency ablation}

Small series of medially inoperable patients report local relapse rates of $8-53 \%$ [317-319]. The ideal patient for radiofrequency ablation would have an isolated, peripheral lesion of $<3 \mathrm{~cm}$ and be able to tolerate a pneumothorax [320]. These series reported that the technique is safe.

\section{Photodynamic therapy}

Photodynamic therapy is a treatment option for stage 0 (TisN0M0) and stage I (T1N0M0) centrally located early stage lung cancer. Photodynamic therapy can preserve lung function, can be repeated, and can be combined with other therapeutic modalities such as chemotherapy. Complete response rates after photodynamic therapy are in the range of $70-92 \%$ [321-324].

\section{Recommendations}

1) Radiation alone for medically inoperable NSCLC must be regarded as the best established alternative treatment to surgery. Level of evidence 1; grade of recommendation B.

2) The use of CHART must be preferred to conventional radiotherapy as it achieves better local control rates and survival. Level of evidence 1; grade of recommendation B.

3) Stereotactic radiotherapy should be considered a good alternative to surgery and conventional radiotherapy in stage I NSCLC patients at high surgical risk. Level of evidence 2++; grade of recommendation $\mathrm{B}$.

\section{Statement}

Other treatment options for selected medically inoperable patients include radiofrequency ablation and photodynamic therapy. Level of evidence $2+$.

\section{WHO SHOULD TREAT THORACIC PATIENTS AND WHERE SHOULD THEY BE TREATED?}

\section{Multidisciplinary management}

The American College of Chest Physicians guidelines [34] and other studies [325] support multidisciplinary management showing significant survival improvement.

\section{Quality of lung cancer surgery}

In Europe, there is a lack of homogeneity in the way the thoracic surgical specialty is practised [326]. In this regard, a joint ESTS/European Association for Cardio-thoracic Surgery task force has defined the requirements necessary to exploit a modern thoracic surgical practice [327]. 
The thoracic surgeon's specialisation

As demonstrated by many studies, qualified thoracic surgeons achieved better results compared to nonspecialised surgeons [328-330] in terms of peri-operative mortality and resection rates.

\section{The surgical volume}

Several authors [331-334], although not all [335-338], have found an inverse relationship between surgical volume and post-operative morbidity and mortality rates, and even longterm survival of lung cancer patients.

\section{Quality indicators}

Post-operative mortality, however, may not be the most appropriate end-point to evaluate the quality of care [179, $339,340]$.

\section{Quality of radiotherapy}

There is only one study demonstrating an impact of institutional experience measured by the volume of cases treated by chemo-radiotherapy [341].

Standard dosage with a daily treatment and $\geqslant 60$ Gy over a 6 week period is recommended for routine practice by the European Lung Cancer Working Party. The EORTC Radiotherapy Group recommendations should be followed for treatment planning and administration of radiotherapy for lung cancer [299, 342, 343]. Those recommendations concern patient's positioning, planning CT scan (with the use of spiral CT scan), accounting for tumour mobility, generating target volumes, treatment planning (has to be three-dimensional), treatment delivery and evaluation of response and toxicity.

\section{Volume of chemo-radiotherapy}

The RTOG study showed that institutions that treated less than five patients had significantly much poorer results than those which treated more patients by chemo-radiotherapy, with respective median survival times of 13.4 and 20.5 months [341]. Multivariate analysis confirmed that the number of patients enrolled from each institution was an important prognostic factor.

\section{Recommendations}

1) The management of lung cancer patients must be performed by multidisciplinary teams (a thoracic surgeon specialising in lung cancer, a medical oncologist, a radiation oncologist and a pulmonologist). Level of evidence $2++$; grade of recommendation B.

2) The surgical treatment of lung cancer patients must be performed in specialised centres by qualified thoracic surgeons, since specialisation has been shown to have a positive impact on resectability, post-operative mortality and long-term survival. Level of evidence 2++; grade of recommendation $\mathrm{B}$.

3) Surgical volume has been shown to have a positive impact on resectability, post-operative mortality and long-term survival. Lung cancer surgery should be performed in centres with adequate volume of cases (although volume thresholds reported in the literature varied in size and definition, a minimum surgical volume of 20-25 major lung resections per year, lobectomy or pneumonectomy, should be advised). Level of evidence 2+; grade of recommendation $\mathrm{C}$.
4) There is a positive impact of volume on the results of chemoradiotherapy. Radiotherapy should be performed by radiotherapists in centres that routinely treat patients by this combined modality. Radiotherapy should be performed according to the EORTC Radiotherapy Group recommendations. Radiotherapy quality: level of evidence 4; grade of recommendation D. Hospital volume: level of evidence 2++; grade of recommendation $\mathrm{C}$.

\section{ALGORITHM FOR THE ASSESSMENT OF RISK BEFORE LUNG RESECTION}

Based on the best available scientific evidence and consensus opinion of experts, the task force produced a functional algorithm for the evaluation of candidates for lung resection.

A decision was made to use, as a template, the algorithm originally proposed by BOLLIGER and PERRUCHOUd [59], representing the only one prospectively validated [84, 110112].

The panel of experts agreed to emphasise the importance and role of exercise tests in the work-up of lung resection candidates. As cycle-ergometry may be not readily available in some centres, a low-technology exercise test, such as the stair climbing test, has been proposed to be a possible surrogate and a first-line screening ergometric step in the algorithm, with the strong recommendation, however, that if the performance on the stair climbing test is poor, patients need to be referred for formal CPET.

The task force team agreed to update and modify the algorithm based on the latest evidence [344, 345] showing that, owing to the advances in surgical techniques (minimally invasive procedures, combination of lung cancer surgery with LVRS [178]) and the ongoing improvement in post-operative care, the limits of functional operability are constantly being lowered, thus allowing resections in patients who would have been deemed inoperable a few years ago. The algorithm emphasises the importance of a preliminary cardiological assessment (fig. 1). Those patients at low cardiological risk or with an optimised cardiological treatment may proceed with pulmonary evaluation (fig. 2). Complete spirometry and DL,CO assessment is recommended in all patients. All those patients with either FEV1 or DL,CO or both $<80 \%$ pred should undergo an ergometric assessment. Ideally, a formal CPET with $V_{\mathrm{O}_{2}}$,peak measurement should be performed, but the group recognised that many centres may have logistical problems in systematically performing this test. In this latter circumstance, a lowtechnology exercise test, preferentially stair climbing test (or, as second choice, shuttle walk test) may be used as screening test. Those patients showing suboptimal performance on these tests $(<22 \mathrm{~m}$ for stair climbing) should necessarily perform a formal CPET.

A limitation of such an algorithm, which is centred on the ergometric evaluation, may be that a certain proportion of lung resection candidates may be unable to perform any type of reliable exercise test due to concomitant incapacitating comorbidities. Such patients have been shown to have an increased risk of death after major lung resection [346] and, after a careful selection based on the available cardiac and pulmonary parameters, they should be regarded as high-risk 
patients and monitored in an advanced care management setting.

\section{LIMITATIONS AND PERSPECTIVES}

Most of the evidence in these guidelines is of level 2, and most of the recommendations are at B or C levels. This is mainly due to the nature of the subject, which makes the design of randomised trials difficult and impractical. Recommendations for risk stratification for radical treatment were thus generated based on the best available scientific evidences and, in case these were weak or totally absent, consensus of expert opinions.

Although age has been traditionally regarded as a risk factor, we concur with recent recommendations [34] that age alone should not be used as selection criteria for surgery. The increased risk for radical treatment observed in elderly patients is probably a function of the underlying comorbidities. In this regard, we recommend that cardiopulmonary fitness of elderly ( $>70 \mathrm{yrs}$ ) or very elderly ( $>80 \mathrm{yrs}$ ) lung cancer patients should be fully evaluated following the recommendations expressed by this task force, without any prejudice for age.

Contrary to lung resection, for which the scientific evidences are more robust, we were unable to recommend any specific test, cut-off value, or algorithm for chemo-radiotherapy, owing to the lack of data. Studies aimed at establishing strategies for the assessment of fitness before chemo-radiotherapy should be strongly encouraged.

The algorithm elaborated by this current task force needs to be prospectively validated. In addition, measurements of mortality, post-operative morbidity and long-term disability should be performed for each treatment arm, in order to evaluate the balance between benefits and risks related to each treatment option. This step is crucial, on order to provide valuable information on treatment options and risks to patients. To date, data available in the literature do not allow this goal to be reached.

Although we designed these guidelines to be broadly accepted, implemented and validated in all European centres, the scientific evidence upon which they were based were mainly generated in settings specialised in the management of lung cancer patients. Treatment of these patients outside these settings is strongly discouraged and application of our guidelines and recommendations outside specialist centres is unwarranted.

\section{STATEMENT OF INTEREST}

None declared.

\section{ACKNOWLEDGEMENTS}

The author affiliations are as follows. A. Brunelli: Division of Thoracic Surgery, Umberto I Regional Hospital, Ancona, Italy. A. Charloux: Service de Physiologie et d'Explorations Fonctionnelles, Hopitaux Universitaires de Strasbourg, Strasbourg, France. C.T. Bolliger : Division of Pulmonology, Dept of Medicine, Faculty of Health Sciences, University of Stellenbosch, Cape Town, South Africa. G. Rocco: Division of Thoracic Surgery, National Cancer Institute, Pascale Foundation, Naples, Italy. J-P. Sculier: Depts of Intensive Care and Thoracic Oncology, Institut Jules Bordet, Centre des Tumeurs de l'Université Libre de Bruxelles (ULB), Brussels, Belgium. G. Varela: Division of Thoracic Surgery, Salamanca University Hospital,
Salamanca, Spain. M. Licker: Dept of Anesthesiology, Pharmacology and Intensive Care, Faculty of Medicine, University Hospital of Geneva, Geneva, Switzerland. M.K. Ferguson: Dept of Surgery, University of Chicago, Chicago, IL, USA. C. Faivre-Finn: Dept of Clinical Oncology, The Christie NHS Foundation Trust, Manchester, UK. R.M. Huber: Division of Respiratory Medicine, Medizinische KlinikInnenstadt, Ludwig-Maximilians-University, Munich, Germany. E.M. Clini: Institute of Respiratory Diseases, University of Modena-Reggio Emilia, Pavullo, Italy. T. Win: Respiratory Medicine, Lister Hospital, Stevenage, UK. D. De Ruysscher: Dept of Radiation Oncology (Maastro Clinic), Maastricht University Medical Center, GROW, Maastricht, The Netherlands. L. Goldman: Division of General Internal medicine, Columbia University, New York, NY, USA.

\section{REFERENCES}

1 Harbour R, Miller J. A new system for grading recommendations in evidence based guidelines. BMJ 2001; 323: 334-336.

2 Lee TH, Marcantonio ER, Mangione CM, et al. Derivation and prospective validation of a simple index for prediction of cardiac risk of major noncardiac surgery. Circulation 1999; 100: 1043-1049.

3 Gilbert K, Larocque BJ, Patrick LT. Prospective evaluation of cardiac risk indices for patients undergoing noncardiac surgery. Ann Intern Med 2000; 133: 356-359.

4 Kumar R, McKinney WP, Raj G, et al. Adverse cardiac events after surgery: assessing risk in a veteran population. J Gen Intern Med 2001; 16: 507-518.

5 Auerbach A, Goldman L. Assessing and reducing the cardiac risk of noncardiac surgery. Circulation 2006; 113: 1361-1376.

6 Fleisher LA, Beckman JA, Brown KA, et al. ACC/AHA 2007 guidelines on perioperative cardiovascular evaluation and care for noncardiac surgery: a report of the American College of Cardiology/American Heart Association Task Force on Practice Guidelines (Writing Committee to Revise the 2002 Guidelines on Perioperative Cardiovascular Evaluation for Noncardiac Surgery): developed in collaboration with the American Society of Echocardiography, American Society of Nuclear Cardiology, Heart Rhythm Society, Society of Cardiovascular Anesthesiologists, Society for Cardiovascular Angiography and Interventions, Society for Vascular Medicine and Biology, and Society for Vascular Surgery. Circulation 2007; 116: e418-e499.

7 Poldermans D, Schouten O, Vidakovic R, et al. A clinical randomized trial to evaluate the safety of a noninvasive approach in high-risk patients undergoing major vascular surgery: the DECREASE-V Pilot Study. J Am Coll Cardiol 2007; 49: 1763-1769.

8 Poldermans D, Bax JJ, Schouten O, et al. Should major vascular surgery be delayed because of preoperative cardiac testing in intermediate-risk patients receiving beta-blocker therapy with tight heart rate control? J Am Coll Cardiol 2006; 48: 964-969.

9 Kertai MD, Boersma E, Bax JJ, et al. A meta-analysis comparing the prognostic accuracy of six diagnostic tests for predicting perioperative cardiac risk in patients undergoing major vascular surgery. Heart 2003; 89: 1327-1334.

10 Rohde LE, Polanczyk CA, Goldman L, et al. Usefulness of transthoracic echocardiography as a tool for risk stratification of patients undergoing major noncardiac surgery. Am J Cardiol 2001; 87: 505-509.

11 Kertai MD, Bountioukos M, Boersma E, et al. Aortic stenosis: an underestimated risk factor for perioperative complications in patients undergoing noncardiac surgery. Am J Med 2004; 116: 8-13.

12 Goldman L. Aortic stenosis in noncardiac surgery: underappreciated in more ways than one? Am J Med 2004; 116: 60-62. 
13 Cheitlin MD, Armstrong WF, Aurigemma GP, et al. ACC/AHA/ ASE 2003 guideline update for the clinical application of echocardiography: summary article: a report of the American College of Cardiology/American Heart Association Task Force on Practice Guidelines (ACC/AHA/ASE Committee to Update the 1997 Guidelines for the Clinical Application of Echocardiography). Circulation 2003; 108: 1146-1162.

14 Fleisher LA. Preoperative evaluation of the patient with hypertension. JAMA 2002; 287: 2043-2046.

15 Ramakrishna G, Sprung J, Ravi BS, et al. Impact of pulmonary hypertension on the outcomes of noncardiac surgery: predictors of perioperative morbidity and mortality. J Am Coll Cardiol 2005; 45: 1691-1699.

16 Warner MA, Lunn RJ, O'Leary PW, et al. Outcomes of noncardiac surgical procedures in children and adults with congenital heart disease. Mayo Perioperative Outcomes Group. Mayo Clin Proc 1998; 73: 728-734.

17 Haering JM, Comunale ME, Parker RA, et al. Cardiac risk of noncardiac surgery in patients with asymmetric septal hypertrophy. Anesthesiology 1996; 85: 254-259.

18 Sandham JD, Hull RD, Brant RF, et al. A randomized, controlled trial of the use of pulmonary-artery catheters in high-risk surgical patients. N Engl J Med 2003; 348: 5-14.

19 Juul AB, Wetterslev J, Gluud C, et al. Effect of perioperative beta blockade in patients with diabetes undergoing major noncardiac surgery: randomised placebo controlled, blinded multicentre trial. BMJ 2006; 332: 1482.

20 Brady AR, Gibbs JS, Greenhalgh RM, et al. Perioperative betablockade (POBBLE) for patients undergoing infrarenal vascular surgery: results of a randomized double-blind controlled trial. $J$ Vasc Surg 2005; 41: 602-609.

21 Yang H, Raymer K, Butler R, et al. The effects of perioperative beta-blockade: results of the Metoprolol after Vascular Surgery (MaVS) study, a randomized controlled trial. Am Heart J 2006; 152: 983-990.

22 Devereaux PJ, Yang H, Yusuf S, et al. Effects of extended-release metoprolol succinate in patients undergoing non-cardiac surgery (POISE trial): a randomised controlled trial. Lancet 2008; 371: 1839-1847.

23 Poldermans D, Boersma E, Bax JJ, et al. The effect of bisoprolol on perioperative mortality and myocardial infarction in high-risk patients undergoing vascular surgery. Dutch Echocardiographic Cardiac Risk Evaluation Applying Stress Echocardiography Study Group. N Engl J Med 1999; 341: 1789-1794.

24 Wijeysundera DN, Naik JS, Beattie WS. $\alpha$-2 adrenergic agonists to prevent perioperative cardiovascular complications: a metaanalysis. Am J Med 2003; 114: 742-752.

25 Stevens RD, Burri H, Tramer MR. Pharmacologic myocardial protection in patients undergoing noncardiac surgery: a quantitative systematic review. Anesth Analg 2003; 97: 623-633.

26 Wallace AW, Galindez D, Salahieh A, et al. Effect of clonidine on cardiovascular morbidity and mortality after noncardiac surgery. Anesthesiology 2004; 101: 284-293.

27 Wijeysundera DN, Beattie WS, Rao V, et al. Calcium antagonists reduce cardiovascular complications after cardiac surgery: a meta-analysis. J Am Coll Cardiol 2003; 41: 1496-1505.

28 Grundy SM, Cleeman JI, Merz CN, et al. Implications of recent clinical trials for the National Cholesterol Education Program Adult Treatment Panel III guidelines. Circulation 2004; 110: 227-239.

29 Kapoor AS, Kanji H, Buckingham J, et al. Strength of evidence for perioperative use of statins to reduce cardiovascular risk: systematic review of controlled studies. BMJ 2006; 333: 1149.

30 McFalls EO, Ward HB, Moritz TE, et al. Coronary-artery revascularization before elective major vascular surgery. $N$ Engl J Med 2004; 351: 2795-2804.
31 Douketis JD, Berger PB, Dunn AS, et al. The perioperative management of antithrombotic therapy: American College of Chest Physicians Evidence-Based Clinical Practice Guidelines (8th Edition). Chest 2008; 133: Suppl. 6, 299S-339S.

32 Newsome LT, Weller RS, Gerancher JC, et al. Coronary artery stents: II. Perioperative considerations and management. Anesth Analg 2008; 107: 570-590.

33 BTS guidelines: guidelines on the selection of patients with lung cancer for surgery. Thorax 2001; 56: 89-108.

34 Colice GL, Shafazand S, Griffin JP, et al. Physiologic evaluation of the patient with lung cancer being considered for resectional surgery: ACCP evidenced-based clinical practice guidelines (2nd edition). Chest 2007; 132: Suppl. 3, 161S-177S.

35 Bolliger CT, Jordan $\mathrm{P}$, Soler $\mathrm{M}$, et al. Exercise capacity as a predictor of postoperative complications in lung resection candidates. Am J Respir Crit Care Med 1995; 151: 1472-1480.

36 Holden DA, Rice TW, Stelmach K, et al. Exercise testing, 6-min walk, and stair climb in the evaluation of patients at high risk for pulmonary resection. Chest 1992; 102: 1774-1779.

37 Markos J, Mullan BP, Hillman DR, et al. Preoperative assessment as a predictor of mortality and morbidity after lung resection. Am Rev Respir Dis 1989; 139: 902-910.

38 Pierce RJ, Copland JM, Sharpe K, et al. Preoperative risk evaluation for lung cancer resection: predicted postoperative product as a predictor of surgical mortality. Am J Respir Crit Care Med 1994; 150: 947-955.

39 Wahi R, McMurtrey MJ, DeCaro LF, et al. Determinants of perioperative morbidity and mortality after pneumonectomy. Ann Thorac Surg 1989; 48: 33-37.

40 Nakahara K, Monden Y, Ohno K, et al. A method for predicting postoperative lung function and its relation to postoperative complications in patients with lung cancer. Ann Thorac Surg 1985; 39: 260-265.

41 Nakahara K, Ohno K, Hashimoto J, et al. Prediction of postoperative respiratory failure in patients undergoing lung resection for lung cancer. Ann Thorac Surg 1988; 46: 549-552.

42 Kearney DJ, Lee TH, Reilly JJ, et al. Assessment of operative risk in patients undergoing lung resection. Importance of predicted pulmonary function. Chest 1994; 105: 753-759.

43 Beccaria M, Corsico A, Fulgoni $\mathrm{P}$, et al. Lung cancer resection: the prediction of postsurgical outcomes should include long-term functional results. Chest 2001; 120: 37-42.

44 Morice RC, Peters EJ, Ryan MB, et al. Exercise testing in the evaluation of patients at high risk for complications from lung resection. Chest 1992; 101: 356-361.

45 Olsen GN, Weiman DS, Bolton JW, et al. Submaximal invasive exercise testing and quantitative lung scanning in the evaluation for tolerance of lung resection. Chest 1989; 95: 267-273.

46 Ribas J, Diaz O, Barbera JA, et al. Invasive exercise testing in the evaluation of patients at high-risk for lung resection. Eur Respir J 1998; 12: 1429-1435.

47 Brunelli A, Al Refai M, Monteverde M, et al. Predictors of early morbidity after major lung resection in patients with and without airflow limitation. Ann Thorac Surg 2002; 74: 999-1003.

48 Carretta A, Zannini P, Puglisi A, et al. Improvement of pulmonary function after lobectomy for non-small cell lung cancer in emphysematous patients. Eur J Cardiothorac Surg 1999; 15: 602-607.

49 Edwards JG, Duthie DJ, Waller DA. Lobar volume reduction surgery: a method of increasing the lung cancer resection rate in patients with emphysema. Thorax 2001; 56: 791-795.

50 Korst RJ, Ginsberg RJ, Ailawadi M, et al. Lobectomy improves ventilatory function in selected patients with severe COPD. Ann Thorac Surg 1998; 66: 898-902.

51 Santambrogio L, Nosotti M, Baisi A, et al. Pulmonary lobectomy for lung cancer: a prospective study to compare patients with 
forced expiratory volume in $1 \mathrm{~s}$ more or less than $80 \%$ of predicted. Eur J Cardiothorac Surg 2001; 20: 684-687.

52 Baldi S, Ruffini E, Harari S, et al. Does lobectomy for lung cancer in patients with chronic obstructive pulmonary disease affect lung function? A multicenter national study. J Thorac Cardiovasc Surg 2005; 130: 1616-1622.

53 Brunelli A, Refai M, Salati M, et al. Predicted versus observed FEV1 and DLCO after major lung resection: a prospective evaluation at different postoperative periods. Ann Thorac Surg 2007; 83: 1134-1139.

54 Brunelli A, Xiume F, Refai M, et al. Evaluation of expiratory volume, diffusion capacity, and exercise tolerance following major lung resection: a prospective follow-up analysis. Chest 2007; 131: 141-147.

55 Sekine $\mathrm{Y}$, Iwata $\mathrm{T}$, Chiyo $\mathrm{M}$, et al. Minimal alteration of pulmonary function after lobectomy in lung cancer patients with chronic obstructive pulmonary disease. Ann Thorac Surg 2003; 76: 356-361.

56 Brunelli A, Sabbatini A, Xiume F, et al. A model to predict the decline of the forced expiratory volume in one second and the carbon monoxide lung diffusion capacity early after major lung resection. Interact Cardiovasc Thorac Surg 2005; 4: 61-65.

57 Varela G, Brunelli A, Rocco G, et al. Evidence of lower alteration of expiratory volume in patients with airflow limitation in the immediate period after lobectomy. Ann Thorac Surg 2007; 84: 417-422.

58 Brunelli A, Refai MA, Salati M, et al. Carbon monoxide lung diffusion capacity improves risk stratification in patients without airflow limitation: evidence for systematic measurement before lung resection. Eur J Cardiothorac Surg 2006; 29: 567-570.

59 Bolliger CT, Perruchoud AP. Functional evaluation of the lung resection candidate. Eur Respir J 1998; 11: 198-212.

60 Ali MK, Ewer MS, Atallah MR, et al. Regional and overall pulmonary function changes in lung cancer. Correlations with tumor stage, extent of pulmonary resection, and patient survival. J Thorac Cardiovasc Surg 1983; 86: 1-8.

61 Berend N, Woolcock AJ, Marlin GE. Effects of lobectomy on lung function. Thorax 1980; 35: 145-150.

62 Corris PA, Ellis DA, Hawkins T, et al. Use of radionuclide scanning in the preoperative estimation of pulmonary function after pneumonectomy. Thorax 1987; 42: 285-291.

63 Olsen GN, Block AJ, Tobias JA. Prediction of postpneumonectomy pulmonary function using quantitative macroaggregate lung scanning. Chest 1974; 66: 13-16.

64 Bolliger CT, Jordan $\mathrm{P}$, Soler M, et al. Pulmonary function and exercise capacity after lung resection. Eur Respir J 1996; 9: 415-421.

65 Pelletier C, Lapointe L, LeBlanc P. Effects of lung resection on pulmonary function and exercise capacity. Thorax 1990; 45: 497-502.

66 Le Roy Ladurie M, Ranson-Bitker B, Merlier M. [Uncertainties of predicted FEV1 after pneumonectomy]. Ann Chir 1985; 39: 459-464.

67 Varela G, Brunelli A, Rocco G, et al. Predicted versus observed FEV1 in the immediate postoperative period after pulmonary lobectomy. Eur J Cardiothorac Surg 2006; 30: 644-648.

68 Varela G, Brunelli A, Rocco G, et al. Measured FEV1 in the first postoperative day, and not ppoFEV1, is the best predictor of cardio-respiratory morbidity after lung resection. Eur J Cardiothorac Surg 2007; 31: 518-521.

69 Brunelli A, Varela G, Rocco G, et al. A model to predict the immediate postoperative FEV1 following major lung resections. Eur J Cardiothorac Surg 2007; 32: 783-786.

70 Miller MR, Hankinson J, Brusasco V, et al. Standardisation of spirometry. Eur Respir J 2005; 26: 319-338.

71 Bates DV, McIlroy MB. Respiratory function after pneumonectomy. Thorax 1956; 11: 303-311.
72 Burrows B, Harrison RW, Adams WE, et al. The postpneumonectomy state: clinical and physiologic observations in thirty-six cases. Am J Med 1960; 28: 281-297.

73 Curtis J, Bauer H, Loomans S, et al. Pulmonary diffusion capacity studies. II. Clinical results using a modified carbon monoxide breathholding technique. Am J Med Sci 1958; 236: 57-64.

74 Dietiker F, Lester W, Burrows B. The effects of thoracic surgery on the pulmonary diffusing capacity. Am Rev Respir Dis 1960; 81 830-838.

75 Boushy SF, Helgason AH, Billig DM, et al. Clinical, physiologic, and morphologic examination of the lung in patients with bronchogenic carcinoma and the relation of the findings to postoperative deaths. Am Rev Respir Dis 1970; 101: 685-695.

76 Ferguson MK, Little L, Rizzo L, et al. Diffusing capacity predicts morbidity and mortality after pulmonary resection. $J$ Thorac Cardiovasc Surg 1988; 96: 894-900.

77 Pieretti P, Alifano M, Roche N, et al. Predictors of an appropriate admission to an ICU after a major pulmonary resection Respiration 2006; 73: 157-165.

78 Santini M, Fiorello A, Vicidomini G, et al. Role of diffusing capacity in predicting complications after lung resection for cancer. Thorac Cardiovasc Surg 2007; 55: 391-394.

79 Wang JS. Relationship of predicted postoperative product to postpneumonectomy cardiopulmonary complications. J Chin Med Assoc 2003; 66: 643-654.

80 Wang JS. Relationship of carbon monoxide pulmonary diffusing capacity to postoperative cardiopulmonary complications in patients undergoing pneumonectomy. Kaohsiung J Med Sci 2003; 19: 437-446.

81 Bousamra M 2nd, Presberg KW, Chammas JH, et al, Early and late morbidity in patients undergoing pulmonary resection with low diffusion capacity. Ann Thorac Surg 1996; 62: 968-974.

82 Ferguson MK, Reeder LB, Mick R. Optimizing selection of patients for major lung resection. J Thorac Cardiovasc Surg 1995; 109: 275-281.

83 Berrisford R, Brunelli A, Rocco G, et al. The European Thoracic Surgery Database project: modelling the risk of in-hospital death following lung resection. Eur J Cardiothorac Surg 2005; 28: 306-311.

84 Loewen GM, Watson D, Kohman L, et al. Preoperative exercise $\mathrm{VO}_{2}$ measurement for lung resection candidates: results of Cancer and Leukemia Group B Protocol 9238. J Thorac Oncol 2007; 2: 619-625.

85 Ferguson MK, Vigneswaran WT. Diffusing capacity predicts morbidity after lung resection in patients without obstructive lung disease. Ann Thorac Surg 2008; 85: 1158-1164.

86 Macintyre N, Crapo RO, Viegi G, et al. Standardisation of the single-breath determination of carbon monoxide uptake in the lung. Eur Respir J 2005; 26: 720-735.

87 Giordano A, Calcagni ML, Meduri G, et al. Perfusion lung scintigraphy for the prediction of postlobectomy residual pulmonary function. Chest 1997; 111: 1542-1547.

88 Giordano A, Calcagni ML, Rossi B, et al. [The scintigraphic prediction of residual lung function after lobectomy in patients with bronchial carcinoma]. Radiol Med (Torino) 1995; 89: 501-505.

89 Wernly JA, DeMeester TR, Kirchner PT, et al. Clinical value of quantitative ventilation-perfusion lung scans in the surgical management of bronchogenic carcinoma. J Thorac Cardiovasc Surg 1980; 80: 535-543.

90 Ali MK, Mountain CF, Ewer MS, et al. Predicting loss of pulmonary function after pulmonary resection for bronchogenic carcinoma. Chest 1980; 77: 337-342.

91 Cordiner A, De Carlo F, De Gennaro R, et al. Prediction of postoperative pulmonary function following thoracic surgery for bronchial carcinoma. Angiology 1991; 42: 985-989.

92 Juhl B, Frost N. A comparison between measured and calculated changes in the lung function after operation for 
pulmonary cancer. Acta Anaesthesiol Scand Suppl 1975; 57: 39-45.

93 Zeiher BG, Gross TJ, Kern JA, et al. Predicting postoperative pulmonary function in patients undergoing lung resection. Chest 1995; 108: 68-72.

94 Win $\mathrm{T}$, Laroche $\mathrm{CM}$, Groves AM, et al. Use of quantitative lung scintigraphy to predict postoperative pulmonary function in lung cancer patients undergoing lobectomy. Ann Thorac Surg 2004; 78: 1215-1218.

95 Bins MC, Wever AM, Pauwels EK, et al. Krypton- $81 \mathrm{~m}$ ventilation studies as a parameter for lung capacity after lobectomy. Eur J Nucl Med 1984; 9: 312-315.

96 Bria WF, Kanarek DJ, Kazemi H. Prediction of postoperative pulmonary function following thoracic operations. Value of ventilation-perfusion scanning. J Thorac Cardiovasc Surg 1983; 86 186-192.

97 Hirose $\mathrm{Y}$, Imaeda $\mathrm{T}$, Doi $\mathrm{H}$, et al. Lung perfusion SPECT in predicting postoperative pulmonary function in lung cancer. Ann Nucl Med 1993; 7: 123-126.

98 Williams AJ, Cayton RM, Harding LK, et al. Quantitative lung scintigrams and lung function in the selection of patients for pneumonectomy. Br J Dis Chest 1984; 78: 105-112.

99 Win T, Tasker AD, Groves AM, et al. Ventilation-perfusion scintigraphy to predict postoperative pulmonary function in lung cancer patients undergoing pneumonectomy. AJR Am J Roentgenol 2006; 187: 1260-1265.

100 Bolliger CT, Guckel C, Engel H, et al. Prediction of functional reserves after lung resection: comparison between quantitative computed tomography, scintigraphy, and anatomy. Respiration 2002; 69: 482-489.

101 Hatabu H, Tadamura E, Levin DL, et al. Quantitative assessment of pulmonary perfusion with dynamic contrast-enhanced MRI. Magn Reson Med 1999; 42: 1033-1038.

102 Iwasawa T, Saito K, Ogawa N, et al. Prediction of postoperative pulmonary function using perfusion magnetic resonance imaging of the lung. J Magn Reson Imaging 2002; 15: 685-692.

103 Levin DL, Chen Q, Zhang M, et al. Evaluation of regional pulmonary perfusion using ultrafast magnetic resonance imaging. Magn Reson Med 2001; 46: 166-171.

104 Liu F, Han P, Feng GS, et al. Using quantitative : CT to predict postoperative pulmonary function in patients with lung cancer. Chin Med J (Engl) 2005; 118: 742-746.

105 Ohno Y, Koyama H, Nogami M, et al. Postoperative lung function in lung cancer patients: comparative analysis of predictive capability of MRI, CT, and SPECT. AJR Am Roentgenol 2007; 189: 400-408.

106 Piai DB, Quagliatto R Jr, Toro I, et al. The use of SPECT in preoperative assessment of patients with lung cancer. Eur Respir J 2004; 24: 258-262.

107 Sverzellati N, Chetta A, Calabro E, et al. Reliability of quantitative computed tomography to predict postoperative lung function in patients with chronic obstructive pulmonary disease having a lobectomy. J Comput Assist Tomogr 2005; 29: 819-824.

108 Wu MT, Pan HB, Chiang AA, et al. Prediction of postoperative lung function in patients with lung cancer: comparison of quantitative $\mathrm{CT}$ with perfusion scintigraphy. $A J R \quad A m$ Roentgenol 2002; 178: 667-672.

109 Benzo R, Kelley GA, Recchi L, et al. Complications of lung resection and exercise capacity: a meta-analysis. Respir Med 2007; 101: 1790-1797.

110 Brutsche $\mathrm{MH}$, Spiliopoulos A, Bolliger CT, et al. Exercise capacity and extent of resection as predictors of surgical risk in lung cancer. Eur Respir J 2000; 15: 828-832.

111 Win $\mathrm{T}$, Jackson A, Sharples L, et al. Cardiopulmonary exercise tests and lung cancer surgical outcome. Chest 2005; 127: $1159-1165$.
112 Wyser C, Stulz P, Soler M, et al. Prospective evaluation of an algorithm for the functional assessment of lung resection candidates. Am J Respir Crit Care Med 1999; 159: 1450-1456.

113 Brunelli A, Belardinelli R, Refai M, et al. Peak oxygen consumption during cardiopulmonary exercise test improves risk stratification in candidates to major lung resection. Chest 2008; [Epub ahead of print PMID: 19029436].

114 Cooper $\mathrm{KH}$. A means of assessing maximal oxygen intake. Correlation between field and treadmill testing. JAMA 1968; 203: 201-204.

115 McGavin CR, Gupta SP, McHardy GJ. Twelve-minute walking test for assessing disability in chronic bronchitis. Br Med J 1976; 1 822-823.

116 Cahalin L, Pappagianopoulos P, Prevost S, et al. The relationship of the 6-min walk test to maximal oxygen consumption in transplant candidates with end-stage lung disease. Chest 1995; 108: 452-459.

117 Bagg LR. The 12-min walking distance; its use in the preoperative assessment of patients with bronchial carcinoma before lung resection. Respiration 1984; 46: 342-345.

118 Morgan AD. Simple exercise testing. Respir Med 1989; 83: 383-387.

119 Singh SJ, Morgan MD, Hardman AE, et al. Comparison of oxygen uptake during a conventional treadmill test and the shuttle walking test in chronic airflow limitation. Eur Respir J 1994; 7: 2016-2020.

120 Swinburn CR, Wakefield JM, Jones PW. Performance, ventilation, and oxygen consumption in three different types of exercise test in patients with chronic obstructive lung disease. Thorax 1985; 40: 581-586.

121 Win T, Jackson A, Groves AM, et al. Comparison of shuttle walk with measured peak oxygen consumption in patients with operable lung cancer. Thorax 2006; 61: 57-60.

122 Win T, Jackson A, Groves AM, et al. Relationship of shuttle walk test and lung cancer surgical outcome. Eur J Cardiothorac Surg 2004; 26: 1216-1219.

123 Van Nostrand D, Kjelsberg MO, Humphrey EW. Preresectional evaluation of risk from pneumonectomy. Surg Gynecol Obstet 1968; 127: 306-312.

124 Olsen GN, Bolton JW, Weiman DS, et al. Stair climbing as an exercise test to predict the postoperative complications of lung resection. Two years' experience. Chest 1991; 99: 587-590.

125 Brunelli A, Refai M, Xiume F, et al. Performance at symptomlimited stair-climbing test is associated with increased cardiopulmonary complications, mortality, and costs after major lung resection. Ann Thorac Surg 2008; 86: 240-247.

126 Ninan M, Sommers KE, Landreneau RJ, et al. Standardized exercise oximetry predicts postpneumonectomy outcome. Ann Thorac Surg 1997; 64: 328-332.

127 Rao V, Todd TR, Kuus A, et al. Exercise oximetry versus spirometry in the assessment of risk prior to lung resection. Ann Thorac Surg 1995; 60: 603-608.

128 Varela G, Cordovilla R, Jimenez MF, et al. Utility of standardized exercise oximetry to predict cardiopulmonary morbidity after lung resection. Eur J Cardiothorac Surg 2001; 19: 351-354.

129 Brunelli A, Refai M, Xiume F, et al. Oxygen desaturation during maximal stair-climbing test and postoperative complications after major lung resections. Eur J Cardiothorac Surg 2008; 33: 77-82.

130 Bechard D, Wetstein L. Assessment of exercise oxygen consumption as preoperative criterion for lung resection. Ann Thorac Surg 1987; 44: 344-349.

131 Bolliger $\mathrm{CT}$, Wyser $\mathrm{C}$, Roser $\mathrm{H}$, et al. Lung scanning and exercise testing for the prediction of postoperative performance in lung resection candidates at increased risk for complications. Chest 1995; 108: 341-348. 
132 Pate P, Tenholder MF, Griffin JP, et al. Preoperative assessment of the high-risk patient for lung resection. Ann Thorac Surg 1996; 61: 1494-1500.

133 Smith TP, Kinasewitz GT, Tucker WY, et al. Exercise capacity as a predictor of post-thoracotomy morbidity. Am Rev Respir Dis 1984; 129: 730-734.

134 Walsh GL, Morice RC, Putnam JB Jr, et al. Resection of lung cancer is justified in high-risk patients selected by exercise oxygen consumption. Ann Thorac Surg 1994; 58: 704-710.

135 ATS/ACCP Statement on cardiopulmonary exercise testing. Am J Respir Crit Care Med 2003; 167: 211-277.

136 Manini TM, Everhart JE, Patel KV, et al. Daily activity energy expenditure and mortality among older adults. JAMA 2006; 296: 171-179.

137 Pitta F, Troosters T, Probst VS, et al. Quantifying physical activity in daily life with questionnaires and motion sensors in COPD. Eur Respir J 2006; 27: 1040-1055.

138 Schonhofer B, Ardes P, Geibel M, et al. Evaluation of a movement detector to measure daily activity in patients with chronic lung disease. Eur Respir J 1997; 10: 2814-2819.

139 Wang JS, Abboud RT, Evans KG, et al. Role of CO diffusing capacity during exercise in the preoperative evaluation for lung resection. Am J Respir Crit Care Med 2000; 162: 1435-1444.

140 Licker MJ, Widikker I, Robert J, et al. Operative mortality and respiratory complications after lung resection for cancer: impact of chronic obstructive pulmonary disease and time trends. Ann Thorac Surg 2006; 81: 1830-1837.

141 Magdeleinat $\mathrm{P}$, Seguin A, Alifano M, et al. Early and long-term results of lung resection for non-small-cell lung cancer in patients with severe ventilatory impairment. Eur J Cardiothorac Surg 2005; 27: 1099-1105.

142 Holloway E, Ram FS. Breathing exercises for asthma. Cochrane Database Syst Rev 2004; 1: CD001277.

143 Lacasse Y, Goldstein R, Lasserson TJ, et al. Pulmonary rehabilitation for chronic obstructive pulmonary disease. Cochrane Database Syst Rev 2006; 4: CD003793.

144 Nici L, Donner C, Wouters E, et al. American Thoracic Society/ European Respiratory Society statement on pulmonary rehabilitation. Am J Respir Crit Care Med 2006; 173: 1390-1413.

145 Bartels MN, Kim H, Whiteson JH, et al. Pulmonary rehabilitation in patients undergoing lung-volume reduction surgery. Arch Phys Med Rehabil 2006; 87: Suppl. 1, S84-S88.

146 Ries AL, Make BJ, Lee SM, et al. The effects of pulmonary rehabilitation in the national emphysema treatment trial. Chest 2005; 128: 3799-3809.

147 Celli BR. Chronic respiratory failure after lung resection: the role of pulmonary rehabilitation. Thorac Surg Clin 2004; 14: 417-428.

148 Palmer SM, Tapson VF. Pulmonary rehabilitation in the surgical patient. Lung transplantation and lung volume reduction surgery. Respir Care Clin N Am 1998; 4: 71-83.

149 Nagamatsu Y, Maeshiro K, Kimura NY, et al. Long-term recovery of exercise capacity and pulmonary function after lobectomy. J Thorac Cardiovasc Surg 2007; 134: 1273-1278.

150 Varela G, Ballesteros E, Jimenez MF, et al. Cost-effectiveness analysis of prophylactic respiratory physiotherapy in pulmonary lobectomy. Eur J Cardiothorac Surg 2006; 29: 216-220.

151 Hulzebos EH, Helders PJ, Favie NJ, et al. Preoperative intensive inspiratory muscle training to prevent postoperative pulmonary complications in high-risk patients undergoing CABG surgery: a randomized clinical trial. JAMA 2006; 296: 1851-1857.

152 Bobbio A, Chetta A, Ampollini L, et al. Preoperative pulmonary rehabilitation in patients undergoing lung resection for nonsmall cell lung cancer. Eur J Cardiothorac Surg 2008; 33: 95-98.

153 Sekine $Y$, Chiyo M, Iwata T, et al. Perioperative rehabilitation and physiotherapy for lung cancer patients with chronic obstructive pulmonary disease. Jpn J Thorac Cardiovasc Surg 2005; 53: 237-243.
154 Lovin S, Bouille S, Orliaguet O, et al. [Preoperative rehabilitation in the surgical treatment of lung cancer]. Pneumologia 2006; 55: 109-112.

155 Moller A, Villebro N. Interventions for preoperative smoking cessation. Cochrane Database Syst Rev 2005; 3: CD002294.

156 Spruit MA, Janssen PP, Willemsen SC, et al. Exercise capacity before and after an 8-week multidisciplinary inpatient rehabilitation program in lung cancer patients: a pilot study. Lung Cancer (Amsterdam, Netherlands) 2006; 52: 257-260.

157 Cesario A, Ferri L, Galetta D, et al. Post-operative respiratory rehabilitation after lung resection for non-small cell lung cancer. Lung Cancer (Amsterdam, Netherlands) 2007; 57: 175-180.

158 Bozzone A, Romanelli A, Magrone G, et al. Pulmonary rehabilitation: pre- and postoperative treatment. Rays 2004; 29 431-433.

159 Nazarian J. Cardiopulmonary rehabilitation after treatment for lung cancer. Curr Treat Options Oncol 2004; 5: 75-82.

160 Nici L. Preoperative and postoperative pulmonary rehabilitation in lung cancer patients. Thorac Surg Clin 2008; 18: 39-43.

161 Ries AL, Bauldoff GS, Carlin BW, et al. Pulmonary Rehabilitation: Joint ACCP/AACVPR Evidence-Based Clinical Practice Guidelines. Chest 2007; 131: Suppl. 5, 4S-42S.

162 American Society of Anesthesiologists. New classification of physical status. Anesthesiology 1963; 24: 111.

163 Battafarano RJ, Piccirillo JF, Meyers BF, et al. Impact of comorbidity on survival after surgical resection in patients with stage I non-small cell lung cancer. J Thorac Cardiovasc Surg 2002; 123: $280-287$.

164 Birim O, Maat AP, Kappetein AP, et al. Validation of the Charlson comorbidity index in patients with operated primary non-small cell lung cancer. Eur J Cardiothorac Surg 2003; 23 30-34.

165 Brunelli A, Fianchini A, Al Refai M, et al. Internal comparative audit in a thoracic surgery unit using the physiological and operative severity score for the enumeration of mortality and morbidity (POSSUM). Eur J Cardiothorac Surg 2001; 19: 924-928.

166 Charlson ME, Pompei P, Ales KL, et al. A new method of classifying prognostic comorbidity in longitudinal studies: development and validation. J Chronic Dis 1987; 40: 373-383.

167 Wang CY, Lin YS, Tzao C, et al. Comparison of Charlson comorbidity index and Kaplan-Feinstein index in patients with stage I lung cancer after surgical resection. Eur J Cardiothorac Surg 2007; 32: 877-881.

168 Epstein SK, Faling LJ, Daly BD, et al. Predicting complications after pulmonary resection. Preoperative exercise testing versus a multifactorial cardiopulmonary risk index. Chest 1993; 104 694-700.

169 Ferguson MK, Durkin AE. A comparison of three scoring systems for predicting complications after major lung resection. Eur J Cardiothorac Surg 2003; 23: 35-42.

170 Melendez JA, Barrera R. Predictive respiratory complication quotient predicts pulmonary complications in thoracic surgical patients. Ann Thorac Surg 1998; 66: 220-224.

171 Harpole DH Jr, DeCamp MM Jr, Daley J, et al. Prognostic models of thirty-day mortality and morbidity after major pulmonary resection. J Thorac Cardiovasc Surg 1999; 117: 969-979.

172 Falcoz PE, Conti M, Brouchet L, et al. The Thoracic Surgery Scoring System (Thoracoscore): risk model for in-hospital death in 15,183 patients requiring thoracic surgery. J Thorac Cardiovasc Surg 2007; 133: 325-332.

173 Birim O, Kappetein AP, Bogers AJ. Charlson comorbidity index as a predictor of long-term outcome after surgery for nonsmall cell lung cancer. Eur J Cardiothorac Surg 2005; 28: 759-762.

174 Birim O, Kappetein AP, Waleboer M, et al. Long-term survival after non-small cell lung cancer surgery: development and validation of a prognostic model with a preoperative and postoperative mode. J Thorac Cardiovasc Surg 2006; 132: 491-498. 
175 Chamogeorgakis TP, Connery CP, Bhora F, et al. Thoracoscore predicts midterm mortality in patients undergoing thoracic surgery. J Thorac Cardiovasc Surg 2007; 134: 883-887.

176 Colinet B, Jacot W, Bertrand D, et al. A new simplified comorbidity score as a prognostic factor in non-small-cell lung cancer patients: description and comparison with the Charlson's index. Br J Cancer 2005; 93: 1098-1105.

177 Moro-Sibilot D, Aubert A, Diab S, et al. Comorbidities and Charlson score in resected stage I nonsmall cell lung cancer. Eur Respir J 2005; 26: 480-486.

178 Alexiou C, Beggs D, Onyeaka P, et al. Pneumonectomy for stage I (T1N0 and T2N0) nonsmall cell lung cancer has potent, adverse impact on survival. Ann Thorac Surg 2003; 76: 1023-1028.

179 Brunelli A, Varela G, Van Schil P, et al. Multicentric analysis of performance after major lung resections by using the European Society Objective Score (ESOS). Eur J Cardiothorac Surg 2008; 33 284-288.

180 Foroulis CN, Kotoulas C, Lachanas $\mathrm{H}$, et al. Factors associated with cardiac rhythm disturbances in the early post-pneumonectomy period: a study on 259 pneumonectomies. Eur J Cardiothorac Surg 2003; 23: 384-389.

181 Licker M, Spiliopoulos A, Frey JG, et al. Risk factors for early mortality and major complications following pneumonectomy for non-small cell carcinoma of the lung. Chest 2002; 121: 1890-1897.

182 Martin J, Ginsberg RJ, Abolhoda A, et al. Morbidity and mortality after neoadjuvant therapy for lung cancer: the risks of right pneumonectomy. Ann Thorac Surg 2001; 72: 1149-1154.

183 Dy SM, Garg P, Nyberg D, et al. Critical pathway effectiveness: assessing the impact of patient, hospital care, and pathway characteristics using qualitative comparative analysis. Health Serv Res 2005; 40: 499-516.

184 Kaltenthaler E, McDonnell A, Peters J. Monitoring the care of lung cancer patients: linking audit and care pathways. J Eval Clin Pract 2001; 7: 13-20.

185 Hanje AJ, Patel T. Preoperative evaluation of patients with liver disease. Nat Clin Pact Gastroenterol Hepatol 2007; 4: 266-276.

186 Brunelli A. Planned admission to an ICU after lung resection: a debatable issue. Respiration 2006; 73: 145-146.

187 Auriant I, Jallot A, Herve $\mathrm{P}$, et al. Noninvasive ventilation reduces mortality in acute respiratory failure following lung resection. Am J Respir Crit Care Med 2001; 164: 1231-1235.

188 Schweizer A, Khatchatourian G, Hohn L, et al. Opening of a new postanesthesia care unit: impact on critical care utilization and complications following major vascular and thoracic surgery. $J$ Clin Anesth 2002; 14: 486-493.

189 Ghosh S, Steyn RS, Marzouk JF, et al. The effectiveness of high dependency unit in the management of high risk thoracic surgical cases. Eur J Cardiothorac Surg 2004; 25: 123-126.

190 Melley DD, Thomson EM, Page SP, et al. Incidence, duration and causes of intensive care unit admission following pulmonary resection for malignancy. Intensive Care Med 2006; 32: 1419-1422.

191 Song SW, Lee HS, Kim JH, et al. Readmission to intensive care unit after initial recovery from major thoracic oncology surgery. Ann Thorac Surg 2007; 84: 1838-1846.

192 Larsen KR, Svendsen UG, Milman N, et al. Cardiopulmonary function at rest and during exercise after resection for bronchial carcinoma. Ann Thorac Surg 1997; 64: 960-964.

193 Nezu K, Kushibe K, Tojo T, et al. Recovery and limitation of exercise capacity after lung resection for lung cancer. Chest 1998; 113: 1511-1516.

194 Nugent AM, Steele IC, Carragher AM, et al. Effect of thoracotomy and lung resection on exercise capacity in patients with lung cancer. Thorax 1999; 54: 334-338.

195 Win T, Groves AM, Ritchie AJ, et al. The effect of lung resection on pulmonary function and exercise capacity in lung cancer patients. Respir Care 2007; 52: 720-726.
196 Oh S, Miyamoto H, Yamazaki A, et al. Prospective analysis of depression and psychological distress before and after surgical resection of lung cancer. Gen Thorac Cardiovasc Surg 2007; 55: 119-124.

197 Brunelli A, Socci L, Refai M, et al. Quality of life before and after major lung resection for lung cancer: a prospective follow-up analysis. Ann Thorac Surg 2007; 84: 410-416.

198 Sugimura H, Yang P. Long-term survivorship in lung cancer: a review. Chest 2006; 129: 1088-1097.

199 Handy JR Jr, Asaph JW, Skokan L, et al. What happens to patients undergoing lung cancer surgery? Outcomes and quality of life before and after surgery. Chest 2002; 122: 21-30.

200 Sarna L, Padilla G, Holmes C, et al. Quality of life of long-term survivors of non-small-cell lung cancer. J Clin Oncol 2002; 20: 2920-2929.

201 Burfeind WR Jr, Tong BC, O'Branski E, et al. Quality of life outcomes are equivalent after lobectomy in the elderly. J Thorac Cardiovasc Surg 2008; 136: 597-604.

202 Salati M, Brunelli A, Xiume F, et al. Quality of life in the elderly after major lung resection for lung cancer. Interact Cardiovasc Thorac Surg 2009; 8: 79-83.

203 Dooms CA, Pat KE, Vansteenkiste JF. The effect of chemotherapy on symptom control and quality of life in patients with advanced non-small cell lung cancer. Exp Rev Anticancer Ther 2006; 6: 531-544.

204 Tanvetyanon T, Soares HP, Djulbegovic B, et al. A systematic review of quality of life associated with standard chemotherapy regimens for advanced non-small cell lung cancer. J Thorac Oncol 2007; 2: 1091-1097.

205 Lederer DJ, Thomashow BM, Ginsburg ME, et al. Lung-volume reduction surgery for pulmonary emphysema: improvement in body mass index, airflow obstruction, dyspnea, and exercise capacity index after 1 year. J Thorac Cardiovasc Surg 2007; 133: 1434-1438.

206 Ramsey SD, Shroyer AL, Sullivan SD, et al. Updated evaluation of the cost-effectiveness of lung volume reduction surgery. Chest 2007; 131: 823-832.

207 Stoller JK, Gildea TR, Ries AL, et al. Lung volume reduction surgery in patients with emphysema and alpha- 1 antitrypsin deficiency. Ann Thorac Surg 2007; 83: 241-251.

208 Fishman A, Martinez F, Naunheim K, et al. A randomized trial comparing lung-volume-reduction surgery with medical therapy for severe emphysema. N Engl J Med 2003; 348: 2059-2073.

209 Tiong LU, Davies R, Gibson PG, et al. Lung volume reduction surgery for diffuse emphysema. Cochrane Database Syst Rev 2006; 4: CD001001.

210 Meyers BF, Yusen RD, Guthrie TJ, et al. Results of lung volume reduction surgery in patients meeting a national emphysema treatment trial high-risk criterion. J Thorac Cardiovasc Surg 2004; 127: 829-835.

211 Naunheim KS, Wood DE, Mohsenifar Z, et al. Long-term followup of patients receiving lung-volume-reduction surgery versus medical therapy for severe emphysema by the National Emphysema Treatment Trial Research Group. Ann Thorac Surg 2006; 82: 431-443.

212 Choong CK, Meyers BF, Battafarano RJ, et al. Lung cancer resection combined with lung volume reduction in patients with severe emphysema. J Thorac Cardiovasc Surg 2004; 127: 1323-1331.

213 DeMeester SR, Patterson GA, Sundaresan RS, et al. Lobectomy combined with volume reduction for patients with lung cancer and advanced emphysema. J Thorac Cardiovasc Surg 1998; 115: 681-688.

214 DeRose JJ Jr, Argenziano M, El-Amir N, et al. Lung reduction operation and resection of pulmonary nodules in patients with severe emphysema. Ann Thorac Surg 1998; 65: 314-318.

215 Keller CA, Naunheim KS, Osterloh J, et al. Histopathologic diagnosis made in lung tissue resected from patients with severe 
emphysema undergoing lung volume reduction surgery. Chest 1997; 111: 941-947.

216 McKenna RJ Jr, Fischel RJ, Brenner M, et al. Combined operations for lung volume reduction surgery and lung cancer. Chest 1996; 110: 885-888.

217 Ojo TC, Martinez F, Paine R 3rd, et al, Lung volume reduction surgery alters management of pulmonary nodules in patients with severe COPD. Chest 1997; 112: 1494-1500.

218 Rozenshtein A, White CS, Austin JH, et al. Incidental lung carcinoma detected at CT in patients selected for lung volume reduction surgery to treat severe pulmonary emphysema. Radiology 1998; 207: 487-490.

219 Schattenberg $T$, Muley $T$, Dienemann $H$, et al. Impact on pulmonary function after lobectomy in patients with chronic obstructive pulmonary disease. Thorac Cardiovasc Surg 2007; 55: 500-504.

220 Garzon JC, Ng CS, Sihoe AD, et al. Video-assisted thoracic surgery pulmonary resection for lung cancer in patients with poor lung function. Ann Thorac Surg 2006; 81: 1996-2003.

221 Bobbio A, Chetta A, Carbognani $\mathrm{P}$, et al. Changes in pulmonary function test and cardio-pulmonary exercise capacity in COPD patients after lobar pulmonary resection. Eur J Cardiothorac Surg 2005; 28: 754-758.

222 Cesario A, Di Toro S, Granone P. Pulmonary lobectomy for cancer in patients with chronic obstructive pulmonary disease. J Thorac Cardiovasc Surg 2006; 132: 215-216.

223 Subotic DR, Mandaric DV, Eminovic TM, et al. Influence of chronic obstructive pulmonary disease on postoperative lung function and complications in patients undergoing operations for primary non-small cell lung cancer. J Thorac Cardiovasc Surg 2007; 134: 1292-1299.

224 Kushibe K, Takahama M, Tojo T, et al. Assessment of pulmonary function after lobectomy for lung cancer - upper lobectomy might have the same effect as lung volume reduction surgery. Eur J Cardiothorac Surg 2006; 29: 886-890.

225 Koizumi K, Haraguchi S, Hirata T, et al. Surgical treatment for lung cancer patients with poor pulmonary function. Ann Thorac Cardiovasc Surg 2005; 11: 87-92.

226 Ginsberg RJ, Rubinstein LV. Randomized trial of lobectomy versus limited resection for T1 N0 non-small cell lung cancer. Lung Cancer Study Group. Ann Thorac Surg 1995; 60: 615-622.

227 Koike $\mathrm{T}$, Yamato $\mathrm{Y}$, Yoshiya $\mathrm{K}$, et al. Intentional limited pulmonary resection for peripheral T1 N0 M0 small-sized lung cancer. J Thorac Cardiovasc Surg 2003; 125: 924-928.

228 Okada M, Nishio W, Sakamoto T, et al. Effect of tumor size on prognosis in patients with non-small cell lung cancer: the role of segmentectomy as a type of lesser resection. J Thorac Cardiovasc Surg 2005; 129: 87-93.

229 Okumura M, Goto M, Ideguchi K, et al. Factors associated with outcome of segmentectomy for non-small cell lung cancer: longterm follow-up study at a single institution in Japan. Lung Cancer (Amsterdam, Netherlands) 2007; 58: 231-237.

230 Warren WH, Faber LP. Segmentectomy versus lobectomy in patients with stage I pulmonary carcinoma. Five-year survival and patterns of intrathoracic recurrence. J Thorac Cardiovasc Surg 1994; 107: 1087-1093.

231 Okada M, Yoshikawa K, Hatta T, et al. Is segmentectomy with lymph node assessment an alternative to lobectomy for nonsmall cell lung cancer of $2 \mathrm{~cm}$ or smaller? Ann Thorac Surg 2001; 71: 956-960.

232 Sienel W, Stremmel C, Kirschbaum A, et al. Frequency of local recurrence following segmentectomy of stage IA non-small cell lung cancer is influenced by segment localisation and width of resection margins - implications for patient selection for segmentectomy. Eur J Cardiothorac Surg 2007; 31: 522-527.
233 Keenan RJ, Landreneau RJ, Maley RH Jr, et al. Segmental resection spares pulmonary function in patients with stage I lung cancer. Ann Thorac Surg 2004; 78: 228-233.

234 Takizawa T, Haga M, Yagi N, et al. Pulmonary function after segmentectomy for small peripheral carcinoma of the lung. $J$ Thorac Cardiovasc Surg 1999; 118: 536-541.

235 Martin-Ucar AE, Nakas A, Pilling JE, et al. A case-matched study of anatomical segmentectomy versus lobectomy for stage I lung cancer in high-risk patients. Eur J Cardiothorac Surg 2005; 27: 675-679.

236 Kraev A, Rassias D, Vetto J, et al. Wedge resection versus lobectomy: 10-year survival in stage I primary lung cancer. Chest 2007; 131: 136-140.

237 Griffin JP, Eastridge CE, Tolley EA, et al. Wedge resection for non-small cell lung cancer in patients with pulmonary insufficiency: prospective ten-year survival. J Thorac Oncol 2006; 1: 960-964.

238 Sienel W, Dango S, Kirschbaum A, et al. Sublobar resections in stage IA non-small cell lung cancer: segmentectomies result in significantly better cancer-related survival than wedge resections. Eur J Cardiothorac Surg 2008; 33: 728-734.

239 El-Sherif A, Gooding WE, Santos R, et al. Outcomes of sublobar resection versus lobectomy for stage I non-small cell lung cancer: a 13-year analysis. Ann Thorac Surg 2006; 82: 408-415.

240 Pastorino U, Valente M, Bedini V, et al. Results of conservative surgery for stage I lung cancer. Tumori 1990; 76: 38-43.

241 Nakayama H, Yamada K, Saito H, et al. Sublobar resection for patients with peripheral small adenocarcinomas of the lung: surgical outcome is associated with features on computed tomographic imaging. Ann Thorac Surg 2007; 84: 1675-1679.

242 Linden PA, Yeap BY, Chang MY, et al. Morbidity of lung resection after prior lobectomy: results from the Veterans Affairs National Surgical Quality Improvement Program. Ann Thorac Surg 2007; 83: 425-431.

243 Berghmans T, Paesmans M, Meert AP, et al. Survival improvement in resectable non-small cell lung cancer with (neo)adjuvant chemotherapy: results of a meta-analysis of the literature. Lung Cancer (Amsterdam, Netherlands) 2005; 49: 13-23.

244 Burdett S, Stewart LA, Rydzewska L. A systematic review and meta-analysis of the literature: chemotherapy and surgery versus surgery alone in non-small cell lung cancer. J Thorac Oncol 2006; 1: 611-621.

245 Depierre A, Milleron B, Moro-Sibilot D, et al. Preoperative chemotherapy followed by surgery compared with primary surgery in resectable stage I (except T1N0), II, and IIIa nonsmall-cell lung cancer. J Clin Oncol 2002; 20: 247-253.

246 Doddoli C, Thomas $\mathrm{P}$, Thirion X, et al. Postoperative complications in relation with induction therapy for lung cancer. Eur J Cardiothorac Surg 2001; 20: 385-390.

247 Roberts JR, Eustis C, Devore R, et al. Induction chemotherapy increases perioperative complications in patients undergoing resection for non-small cell lung cancer. Ann Thorac Surg 2001; 72: 885-888.

248 Stamatis G. Risks of neoadjuvant chemotherapy and radiation therapy. Thorac Surg Clin 2008; 18: 71-80.

249 Brunelli A, Xiume F, Al Refai M, et al. Gemcitabine-cisplatin chemotherapy before lung resection: a case-matched analysis of early outcome. Ann Thorac Surg 2006; 81: 1963-1968.

250 Novoa N, Varela G, Jimenez MF. Morbidity after surgery for non-small cell lung carcinoma is not related to neoadjuvant chemotherapy. Eur J Cardiothorac Surg 2001; 20: 700-704.

251 Perrot E, Guibert B, Mulsant $P$, et al. Preoperative chemotherapy does not increase complications after nonsmall cell lung cancer resection. Ann Thorac Surg 2005; 80: 423-427.

252 Siegenthaler MP, Pisters KM, Merriman KW, et al. Preoperative chemotherapy for lung cancer does not increase surgical morbidity. Ann Thorac Surg 2001; 71: 1105-1111. 
253 Van Schil P, Van Meerbeeck J, Kramer G, et al. Morbidity and mortality in the surgery arm of EORTC 08941 trial. Eur Respir J 2005; 26: 192-197.

254 Venuta F, Anile M, Diso D, et al. Operative complications and early mortality after induction therapy for lung cancer. Eur J Cardiothorac Surg 2007; 31: 714-717.

255 Garrido P, Gonzalez-Larriba JL, Insa A, et al. Long-term survival associated with complete resection after induction chemotherapy in stage IIIA (N2) and IIIB (T4N0-1) non small-cell lung cancer patients: the Spanish Lung Cancer Group Trial 9901. J Clin Oncol 2007; 25: 4736-4742.

256 Gilligan D, Nicolson M, Smith I, et al. Preoperative chemotherapy in patients with resectable non-small cell lung cancer: results of the MRC LU22/NVALT 2/EORTC 08012 multicentre randomised trial and update of systematic review. Lancet 2007; 369: 1929-1937.

257 van Meerbeeck JP, Kramer GW, Van Schil PE, et al. Randomized controlled trial of resection versus radiotherapy after induction chemotherapy in stage IIIA-N2 non-small-cell lung cancer. J Nat Cancer Inst 2007; 99: 442-450.

258 Albain KS, Swann RS, Rusch VR. Phase III study of concurrent chemotherapy and radiotherapy (CT/RT) versus CT/RT followed by surgical resection for stage IIIA (pN20 non-small cell lung cancer: outcomes update of North American Intergroup 0139 (RTOG 9309). J Clin Oncol 2005; 23: Suppl. 624, 7014.

259 Thomas M, Rube C, Hoffknecht P, et al. Effect of preoperative chemoradiation in addition to preoperative chemotherapy: a randomised trial in stage III non-small-cell lung cancer. Lancet Oncol 2008; 9: 636-648.

260 Van Schil PE. Mortality associated with pneumonectomy after induction chemoradiation versus chemotherapy alone in stage IIIA-N2 non-small cell lung cancer. J Thorac Cardiovasc Surg 2008; 135: 718.

261 Daly BD, Fernando HC, Ketchedjian A, et al. Pneumonectomy after high-dose radiation and concurrent chemotherapy for nonsmall cell lung cancer. Ann Thorac Surg 2006; 82: 227-231.

262 Gudbjartsson T, Gyllstedt E, Pikwer A, et al. Early surgical results after pneumonectomy for non-small cell lung cancer are not affected by preoperative radiotherapy and chemotherapy. Ann Thorac Surg 2008; 86: 376-382.

263 Pezzetta E, Stupp R, Zouhair A, et al. Comparison of neoadjuvant cisplatin-based chemotherapy versus radiochemotherapy followed by resection for stage III (N2) NSCLC. Eur J Cardiothorac Surg 2005; 27: 1092-1098.

264 Uy KL, Darling G, Xu W, et al. Improved results of induction chemoradiation before surgical intervention for selected patients with stage IIIA-N2 non-small cell lung cancer. J Thorac Cardiovasc Surg 2007; 134: 188-193.

265 McDonald S, Rubin P, Phillips TL, et al. Injury to the lung from cancer therapy: clinical syndromes, measurable endpoints, and potential scoring systems. Int J Radiat Oncol Biol Phys 1995; 31: 1187-1203.

266 Esteban E, Villanueva N, Muniz I, et al. Pulmonary toxicity in patients treated with gemcitabine plus vinorelbine or docetaxel for advanced non-small cell lung cancer: outcome data on a randomized phase II study. Investig New Drugs 2008; 26: 67-74.

267 Thomas AL, Cox G, Sharma RA, et al. Gemcitabine and paclitaxel associated pneumonitis in non-small cell lung cancer: report of a phase I/II dose-escalating study. Eur J Cancer 2000; 36: 2329-2334.

268 Leo F, Solli P, Spaggiari L, et al. Respiratory function changes after chemotherapy: an additional risk for postoperative respiratory complications? Ann Thorac Surg 2004; 77: 260-265.

269 Maas KW, van der Lee I, Bolt K, et al. Lung function changes and pulmonary complications in patients with stage III non-small cell lung cancer treated with gemcitabine/cisplatin as part of combined modality treatment. Lung Cancer (Amsterdam, Netherlands) 2003; 41: 345-351.

270 Roach M 3rd, Gandara DR, Yuo HS, et al, Radiation pneumonitis following combined modality therapy for lung cancer: analysis of prognostic factors. J Clin Oncol 1995; 13: 2606-2612.

271 Borst GR, De Jaeger K, Belderbos JS, et al. Pulmonary function changes after radiotherapy in non-small-cell lung cancer patients with long-term disease-free survival. Int J Radiat Oncol Biol Phys 2005; 62: 639-644.

272 Rancati T, Ceresoli GL, Gagliardi G, et al. Factors predicting radiation pneumonitis in lung cancer patients: a retrospective study. Radiother Oncol 2003; 67: 275-283.

273 Miller KL, Shafman TD, Marks LB. A practical approach to pulmonary risk assessment in the radiotherapy of lung cancer. Semin Radiat Oncol 2004; 14: 298-307.

274 Inoue A, Kunitoh $\mathrm{H}$, Sekine I, et al. Radiation pneumonitis in lung cancer patients: a retrospective study of risk factors and the long-term prognosis. Int J Radiat Oncol Biol Phys 2001; 49: 649-655.

275 Abratt RP, Willcox PA, Smith JA. Lung cancer in patients with borderline lung functions - zonal lung perfusion scans at presentation and lung function after high dose irradiation. Radiother Oncol 1990; 19: 317-322.

276 Marks LB, Munley MT, Bentel GC, et al. Physical and biological predictors of changes in whole-lung function following thoracic irradiation. Int J Radiat Oncol Biol Phys 1997; 39: 563-570.

277 Lind PA, Marks LB, Hollis D, et al. Receiver operating characteristic curves to assess predictors of radiation-induced symptomatic lung injury. Int J Radiat Oncol Biol Phys 2002; 54: 340-347.

278 Videtic GM, Stitt LW, Ash RB, et al. Impaired diffusion capacity predicts for decreased treatment tolerance and survival in limited stage small cell lung cancer patients treated with concurrent chemoradiation. Lung Cancer (Amsterdam, Netherlands) 2004; 43: 159-166.

279 Robnett TJ, Machtay M, Vines EF, et al. Factors predicting severe radiation pneumonitis in patients receiving definitive chemoradiation for lung cancer. Int J Radiat Oncol Biol Phys 2000; 48: 89-94.

280 Tsujino K, Hirota S, Endo M, et al. Predictive value of dosevolume histogram parameters for predicting radiation pneumonitis after concurrent chemoradiation for lung cancer. Int $J$ Radiat Oncol Biol Phys 2003; 55: 110-115.

281 Fujino $\mathrm{M}$, Shirato $\mathrm{H}$, Onishi $\mathrm{H}$, et al. Characteristics of patients who developed radiation pneumonitis requiring steroid therapy after stereotactic irradiation for lung tumors. Cancer J 2006; 12: 41-46.

282 Choi NC, Kanarek DJ. Toxicity of thoracic radiotherapy on pulmonary function in lung cancer. Lung Cancer (Amsterdam, Netherlands) 1994; 10: Suppl. 1, S219-S230.

283 Kocak Z, Borst GR, Zeng J, et al. Prospective assessment of dosimetric/physiologic-based models for predicting radiation pneumonitis. Int J Radiat Oncol Biol Phys 2007; 67: 178-186.

284 Graham PH, Gebski VJ, Langlands AO. Radical radiotherapy for early nonsmall cell lung cancer. Int J Radiat Oncol Biol Phys 1995; 31: 261-266.

285 Kwa SL, Lebesque JV, Theuws JC, et al. Radiation pneumonitis as a function of mean lung dose: an analysis of pooled data of 540 patients. Int J Radiat Oncol Biol Phys 1998; 42: 1-9.

286 Graham MV, Purdy JA, Emami B, et al. Clinical dose-volume histogram analysis for pneumonitis after 3D treatment for nonsmall cell lung cancer (NSCLC). Int J Radiat Oncol Biol Phys 1999; 45: 323-329.

287 van Baardwijk A, Bosmans G, Boersma L, et al. Individualized radical radiotherapy of non-small-cell lung cancer based on normal tissue dose constraints: a feasibility study. Int J Radiat Oncol Biol Phys 2008; 71: 1394-1401. 
288 Fleckenstein K, Gauter-Fleckenstein B, Jackson IL, et al. Using biological markers to predict risk of radiation injury. Semin Radiat Oncol 2007; 17: 89-98.

289 Chemotherapy in non-small cell lung cancer: a meta-analysis using updated data on individual patients from 52 randomised clinical trials. Non-small Cell Lung Cancer Collaborative Group. BMJ 1995; 311: 899-909.

290 Chemotherapy in addition to supportive care improves survival in advanced non-small-cell lung cancer: a systematic review and meta-analysis of individual patient data from 16 randomized controlled trials. J Clin Oncol 2008; 26: 4617-4625.

291 Vahid B, Marik PE. Pulmonary complications of novel antineoplastic agents for solid tumors. Chest 2008; 133: 528-538.

292 Meadors M, Floyd J, Perry MC. Pulmonary toxicity of chemotherapy. Semin Oncol 2006; 33: 98-105.

293 Gopal R. Pulmonary toxicity associated with the treatment of non-small cell lung cancer and the effects of cytoprotective strategies. Semin Oncol 2005; 32, 2: Suppl. 3, S55-S59.

294 Limper AH. Chemotherapy-induced lung disease. Clin Chest Med 2004; 25: 53-64.

295 Cooper JA Jr, White DA, Matthay RA. Drug-induced pulmonary disease. Part 1: cytotoxic drugs. Am Rev Respir Dis 1986; 133: 321-340.

296 Rowell NP, Williams CJ. Radical radiotherapy for stage I/II nonsmall cell lung cancer in patients not sufficiently fit for or declining surgery (medically inoperable): a systematic review. Thorax 2001; 56: 628-638.

297 Saunders M, Dische S, Barrett A, et al. Continuous, hyperfractionated, accelerated radiotherapy (CHART) versus conventional radiotherapy in non-small cell lung cancer: mature data from the randomised multicentre trial. CHART Steering committee. Radiother Oncol 1999; 52: 137-148.

298 McGibney C, Holmberg O, McClean B, et al. Dose escalation of chart in non-small cell lung cancer: is three-dimensional conformal radiation therapy really necessary? Int J Radiat Oncol Biol Phys 1999; 45: 339-350.

299 Senan S, De Ruysscher D, Giraud P, et al. Literature-based recommendations for treatment planning and execution in highdose radiotherapy for lung cancer. Radiother Oncol 2004; 71: 139-146.

300 Cheung PC, Yeung LT, Basrur V, et al. Accelerated hypofractionation for early-stage non-small-cell lung cancer. Int J Radiat Oncol Biol Phys 2002; 54: 1014-1023.

301 Slotman BJ, Antonisse IE, Njo KH. Limited field irradiation in early stage (T1-2N0) non-small cell lung cancer. Radiother Oncol 1996; 41: 41-44.

302 Bradley J, Graham MV, Winter K, et al. Toxicity and outcome results of RTOG 9311: a phase I-II dose-escalation study using three-dimensional conformal radiotherapy in patients with inoperable non-small-cell lung carcinoma. Int J Radiat Oncol Biol Phys 2005; 61: 318-328.

303 Chen M, Hayman JA, Ten Haken RK, et al. Long-term results of high-dose conformal radiotherapy for patients with medically inoperable T1-3N0 non-small-cell lung cancer: is low incidence of regional failure due to incidental nodal irradiation? Int J Radiat Oncol Biol Phys 2006; 64: 120-126.

304 Rosenzweig KE, Fox JL, Yorke E, et al. Results of a phase I doseescalation study using three-dimensional conformal radiotherapy in the treatment of inoperable nonsmall cell lung carcinoma. Cancer 2005; 103: 2118-2127.

305 Beitler JJ, Badine EA, El-Sayah D, et al. Stereotactic body radiation therapy for nonmetastatic lung cancer: an analysis of 75 patients treated over 5 years. Int J Radiat Oncol Biol Phys 2006; 65: 100-106.

306 McGarry RC, Papiez L, Williams M, et al. Stereotactic body radiation therapy of early-stage non-small-cell lung carcinoma: phase I study. Int J Radiat Oncol Biol Phys 2005; 63: 1010-1015.
307 Nyman J, Johansson KA, Hulten U. Stereotactic hypofractionated radiotherapy for stage I non-small cell lung cancer - mature results for medically inoperable patients. Lung Cancer (Amsterdam, Netherlands) 2006; 51: 97-103.

308 Onishi H, Kuriyama K, Komiyama T, et al. Clinical outcomes of stereotactic radiotherapy for stage I non-small cell lung cancer using a novel irradiation technique: patient self-controlled breath-hold and beam switching using a combination of linear accelerator and CT scanner. Lung Cancer (Amsterdam, Netherlands) 2004; 45: 45-55.

309 Timmerman R, McGarry R, Yiannoutsos C, et al. Excessive toxicity when treating central tumors in a phase II study of stereotactic body radiation therapy for medically inoperable early-stage lung cancer. J Clin Oncol 2006; 24: 4833-4839.

310 Zimmermann FB, Geinitz H, Schill S, et al. Stereotactic hypofractionated radiation therapy for stage I non-small cell lung cancer. Lung Cancer (Amsterdam, Netherlands) 2005; 48: 107-114.

311 Fukumoto S, Shirato H, Shimzu S, et al. Small-volume imageguided radiotherapy using hypofractionated, coplanar, and noncoplanar multiple fields for patients with inoperable Stage I nonsmall cell lung carcinomas. Cancer 2002; 95: 1546-1553.

312 Nagata Y, Takayama K, Matsuo Y, et al. Clinical outcomes of a phase I/II study of 48 Gy of stereotactic body radiotherapy in 4 fractions for primary lung cancer using a stereotactic body frame. Int J Radiat Oncol Biol Phys 2005; 63: 1427-1431.

313 Onishi H, Araki T, Shirato H, et al. Stereotactic hypofractionated high-dose irradiation for stage I nonsmall cell lung carcinoma: clinical outcomes in 245 subjects in a Japanese multiinstitutional study. Cancer 2004; 101: 1623-1631.

314 Timmerman R, Papiez L, Suntharalingam M. Extracranial stereotactic radiation delivery: expansion of technology beyond the brain. Technol Cancer Res Treat 2003; 2: 153-160.

315 Uematsu M, Shioda A, Suda A, et al. Computed tomographyguided frameless stereotactic radiotherapy for stage I non-small cell lung cancer: a 5-year experience. Int J Radiat Oncol Biol Phys 2001; 51: 666-670.

316 Uno T, Aruga T, Isobe $\mathrm{K}$, et al. Radiation bronchitis in lung cancer patient treated with stereotactic radiation therapy. Radiat Med 2003; 21: 228-231.

317 Dupuy DE, DiPetrillo T, Gandhi S, et al. Radiofrequency ablation followed by conventional radiotherapy for medically inoperable stage I non-small cell lung cancer. Chest 2006; 129: 738-745.

318 Hiraki T, Gobara H, lishi T, et al. Percutaneous radiofrequency ablation for clinical stage I non-small cell lung cancer: results in 20 nonsurgical candidates. J Thorac Cardiovasc Surg 2007; 134 1306-1312.

319 Pennathur A, Luketich JD, Abbas G, et al. Radiofrequency ablation for the treatment of stage I non-small cell lung cancer in high-risk patients. J Thorac Cardiovasc Surg 2007; 134: 857-864.

320 Fernando HC, Hoyos AD, Litle V, et al. Radiofrequency ablation: identification of the ideal patient. Clin Lung Cancer 2004; 6: 149-153.

321 Cortese DA, Edell ES, Kinsey JH. Photodynamic therapy for early stage squamous cell carcinoma of the lung. Mayo Clin Proc 1997; 72: 595-602.

322 Furukawa K, Okunaka T, Tsuchida T. A phase I clinical study of photodynamic therapy for early stage lung carcinoma using ME2906 and a diode laser system. Porphyrins 1998; 7: 199-206.

323 Furuse K, Fukuoka M, Kato H, et al. A prospective phase II study on photodynamic therapy with photofrin II for centrally located early-stage lung cancer. The Japan Lung Cancer Photodynamic Therapy Study Group. J Clin Oncol 1993; 11: 1852-1857.

324 Kato H, Furukawa K, Sato M, et al. Phase II clinical study of photodynamic therapy using mono-L-aspartyl chlorin e6 and diode laser for early superficial squamous cell carcinoma of the lung. Lung Cancer (Amsterdam, Netherlands) 2003; 42: 103-111. 
325 Forrest LM, McMillan DC, McArdle CS, et al. An evaluation of the impact of a multidisciplinary team, in a single centre, on treatment and survival in patients with inoperable non-small-cell lung cancer. Br J Cancer 2005; 93: 977-978.

326 Le Pimpec-Barthes F, Bagan P, Hubsch JP, et al. [Evaluation of thoracic surgical practice. The impact of specialisation and the effect of volume on the results of cancer treatment: resectability, post-operative mortality, and long-term survivall. Rev Mal Respir 2006; 23: Suppl. 4, 13S73-13S85.

327 Klepetko W, Aberg TH, Lerut AE, et al. Structure of general thoracic surgery in Europe. Eur J Cardiothorac Surg 2001; 20: 663-668.

328 Goodney PP, Lucas FL, Stukel TA, et al. Surgeon specialty and operative mortality with lung resection. Ann Surg 2005; 241: 179-184.

329 Martin-Ucar AE, Waller DA, Atkins JL, et al. The beneficial effects of specialist thoracic surgery on the resection rate for nonsmall-cell lung cancer. Lung Cancer (Amsterdam, Netherlands) 2004; 46: 227-232.

330 Silvestri GA, Handy J, Lackland D, et al. Specialists achieve better outcomes than generalists for lung cancer surgery. Chest 1998, 114: 675-680.

331 Bach PB, Cramer LD, Schrag D, et al. The influence of hospital volume on survival after resection for lung cancer. $N$ Engl J Med 2001; 345: 181-188.

332 Birkmeyer JD, Stukel TA, Siewers AE, et al. Surgeon volume and operative mortality in the United States. N Engl J Med 2003; 349: 2117-2127.

333 Lien YC, Huang MT, Lin HC. Association between surgeon and hospital volume and in-hospital fatalities after lung cancer resections: the experience of an Asian country. Ann Thorac Surg 2007; 83: 1837-1843.

334 Little AG, Rusch VW, Bonner JA, et al. Patterns of surgical care of lung cancer patients. Ann Thorac Surg 2005; 80: 2051-2056.

335 Begg CB, Cramer LD, Hoskins WJ, et al. Impact of hospital volume on operative mortality for major cancer surgery. JAMA 1998; 280: 1747-1751.

336 Freixinet JL, Julia-Serda G, Rodriguez PM, et al. Hospital volume: operative morbidity, mortality and survival in thoracotomy for lung cancer. A Spanish multicenter study of 2994 cases. Eur J Cardiothorac Surg 2006; 29: 20-25.

337 Treasure T, Utley M, Bailey A. Assessment of whether inhospital mortality for lobectomy is a useful standard for the quality of lung cancer surgery: retrospective study. BMJ 2003; 327: 73 .

338 Urbach DR, Bell CM, Austin PC. Differences in operative mortality between high- and low-volume hospitals in Ontario for 5 major surgical procedures: estimating the number of lives potentially saved through regionalization. CMAJ 2003; 168 1409-1414.

339 Brunelli A, Rocco G. Clinical and nonclinical indicators of performance in thoracic surgery. Thorac Surg Clin 2007; 17: 369-377.

340 Damhuis R, Coonar A, Plaisier P, et al. A case-mix model for monitoring of postoperative mortality after surgery for lung cancer. Lung Cancer (Amsterdam, Netherlands) 2006; 51: 123-129.

341 Lee JS, Scott CB, Komaki R, et al. Impact of institutional experience on survival outcome of patients undergoing combined chemoradiation therapy for inoperable non-small-cell lung cancer. Int J Radiat Oncol Biol Phys 2002; 52: 362-370.

342 [Management of resectable non-small cell lung cancer. Guidelines of clinical practice made by the European Lung Cancer Working Party]. Reoue medicale de Bruxelles 2006; 27: 29-38.

343 Alexopoulos C, Berghmans T, Berchier M, et al. European Lung Cancer Working Party guidelines for non small cell lung cancer. II. Unresectable non-metastatic stages. Hospital Chronicles 2006; 1: 108-117.

344 Brunelli A. Algorithm for functional evaluation of the lung resection candidates: time for reappraisal? Respiration 2009; [Epub ahead of print PMID: 19325230].

345 Bolliger CT. Functional reserve before lung resection: how low can we go? Respiration 2009; [Epub ahead of print PMID 19407438].

346 Brunelli A, Sabbatini A, Xiume F, et al. Inability to perform maximal stair climbing test before lung resection: a propensity score analysis on early outcome. Eur J Cardiothorac Surg 2005; 27: $367-372$. 